\title{
Sedimentary and U-Pb detrital zircons provenance of the Paleoproterozoic Piracicaba and Sabará groups, Quadrilátero Ferrífero, Southern São Francisco craton, Brazil
}

\author{
Luiz Fernandes Dutra ${ }^{*}$ (D), Maximiliano Martins ${ }^{1}$ (D), Cristiano Lana ${ }^{1}$ (D)
}

\begin{abstract}
The Quadrilátero Ferrífero is an important mineral province located in Southern São Francisco craton, SE Brazil. Its prominent feature is the Gandarela syncline that was formed as part of the regional deformation event in the southernmost part of the craton at ca. 2,000 Ma. The syncline exposes several economically important units of Rio das Velhas and Minas supergroups, widely known for their gold and iron ore mineral deposits. This work focused on the upper Minas Supergroup — Cercadinho Formation and Sabará Group in the Gandarela syncline. We showed detail stratigraphic surveys combined with U-Pb detrital zircon analysis. Data reveal the development of high- to low-density turbidity systems. The first one is related to the deposition of Cercadinho Formation that marks the siliciclastic infilling of the Minas basin. For the Sabará Group, a fine turbidite system of foredeep depocenter is inferred. The detrital zircon analysis indicates that their sediments were derived from Archean, Rhyacian, and Orosirian exhumed terrains, besides granitoids positioned to the south and east of Quadrilátero Ferrifero. We proposed the age of 2,036 $\pm 25 \mathrm{Ma}$ as the maximum age of deposition of Sabará Group, whose sedimentation occurs in the first stages of Minas accretionary orogeny.
\end{abstract}

KEYWORDS: Detrital zircons; Quadrilátero Ferrífero; Minas basin; Gandarela syncline; Cercadinho Formation; Sabará Group.

\section{INTRODUCTION}

Minas Supergroup of Quadrilátero Ferrífero ("Iron Quadrangle") in Southeast Brazil is a natural laboratory for its tectonic conformation and mineral deposits, especially those of metallic filiation. This supergroup records a continental rift to passive margin and synorogenic sedimentation from the late Neoarchean to Rhyacian/Orosirian period (Dorr II 1969, Machado \& Carneiro 1992, Alkmim \& Marshak 1998). The absence of fossils, crosscutting igneous intrusion and interlayered volcanic beds, constitutes the main problems in the geochronological studies of Minas basin (Martínez-Dopico et al.2017). This gap has recently been filled through the integration of geochronological data of detrital zircons associated with stratigraphic surveys of scattered areas in and around Quadrilátero Ferrífero (Hartmann et al. 2006, Cabral et al. 2012, Mendes et al. 2014, Farina et al. 2016, Martínez-Dopico et al. 2017). However, despite the available data, important areas in Quadrilátero Ferrífero that host large deposits of banded iron

\section{Supplementary material}

Supplementary data associated with this article can be found in the online version: Supplementary Table 1.

${ }^{1}$ Universidade Federal de Ouro Preto - Ouro Preto (MG), Brazil. E-mails: dutrluiz@gmail.com, maximilianomartins@yahoo.com.br, cristianodeclana@gmail.com

${ }^{*}$ Corresponding author.

(c) 2019 The autors. This is an open access article distributed under the terms of the Creative Commons license. formation and iron ore remain poorly investigated in terms of stratigraphic architecture and $\mathrm{U}-\mathrm{Pb}$ geochronology.

The Gandarela syncline is one of the regional folds that underlie the set of Quadrilatero Ferrifero plateaus in its northeast portion. This syncline exposes a full section of Minas Supergroup and hosts significant deposits of iron ore and gold (Moore 1969). In this paper, we investigated the depositional environments and sedimentary provenance of the upper Minas Supergroup based on the detail stratigraphic analysis (1:100) and U-Pb dating of detrital zircon. We described the architecture of internal facies from Cercadinho Formation (Piracicaba Group) and Sabará Group in the Gandarela syncline. Our results recognized new source areas to their sediments, as well as part of the geotectonic setting that operates during the sedimentation.

\section{REGIONAL BACKGROUND}

The São Francisco Craton in the Eastern portion of the Brazilian shield is surrounded by Neoproterozoic orogenic belts (Almeida 1977, Almeida et al. 1981), as seen in Figure 1. The craton comprises (Teixeira \& Figueiredo 1991, Barbosa \& Sabaté 2004, Sial et al. 2009, Alkmim \& Martins-Neto 2012):

1. Archean nuclei and Paleoproterozoic igneous intrusions;

2. Archean greenstone belts;

3. Paleo- to Neoproterozoic sedimentary successions locally metamorphosed;

4. granitic intrusions, pegmatite veins and mafic suits of Paleoproterozoic to Mesozoic age;

5. Phanerozoic sedimentary covers. 
The Archaean nuclei are made up of a mosaic of individual elongated blocks bounded by Paleoproterozoic orogenic domains (Alkmim \& Martins-Neto 2012, Teixeira et al. 2017) in the Northeastern portion of the craton. The Southern segment is subdivided into several gneiss-granitic domes (Bonfim, Belo Horizonte, Bação and Santa Bárbara complexes) bounded by Archean-Paleoproterozoic metavolcanossedimentary rocks that host the Quadrilátero Ferrífero
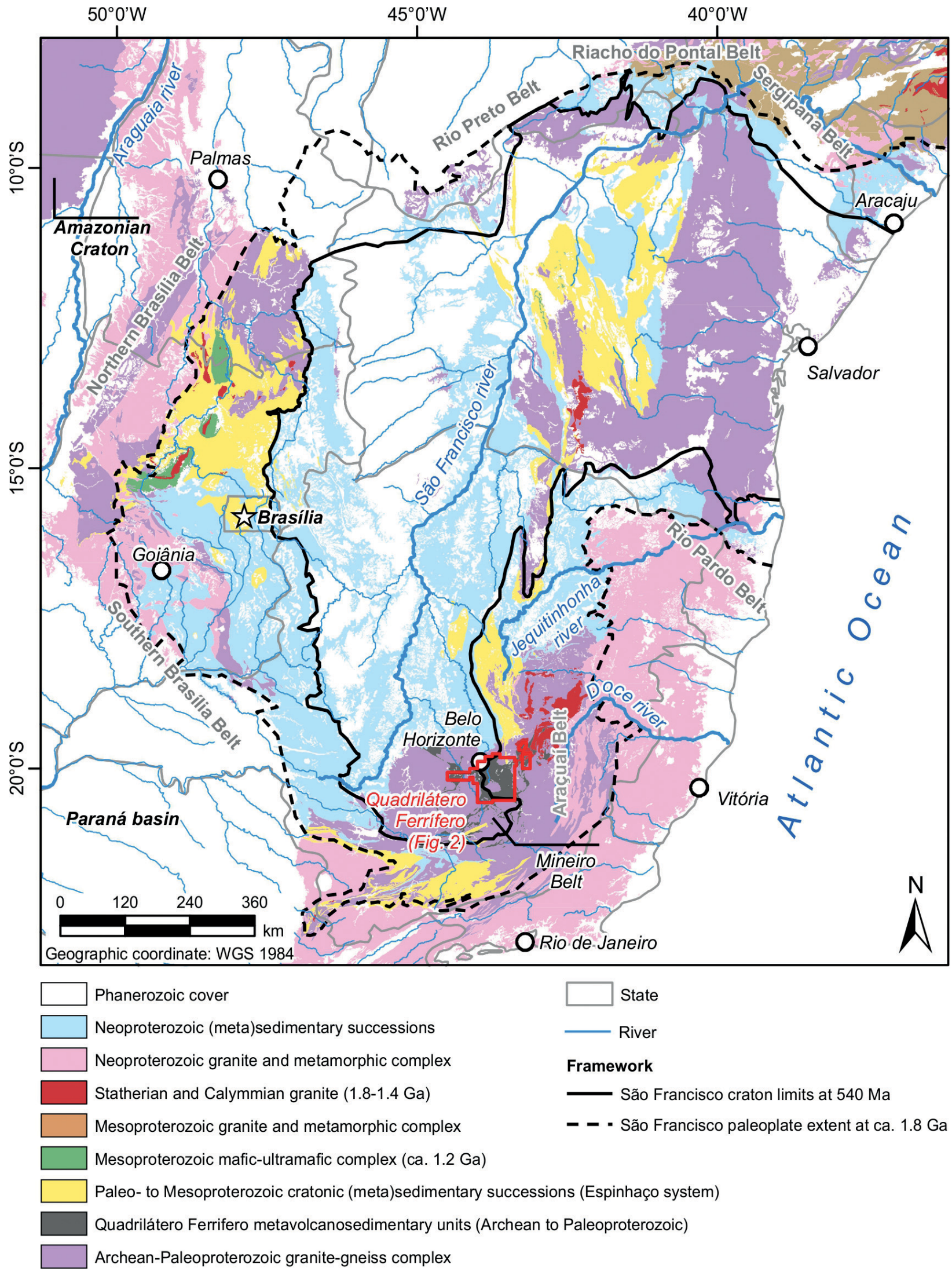

Figure 1. Geological map of the São Francisco craton (based on Guadagnin \& Chemale Jr. 2015). The black lines indicate the most accepted extent of the craton at ca. $540 \mathrm{Ma}$ and the previously accepted extent of the São Francisco paleoplate at ca. 1.8 Ga (after Guimarães et al. 2014). Name of the Neoproterozoic belt is given in gray. This map was generated from the Geological Survey of Brazil (Companhia de Pesquisa de Recursos Minerais, CPRM) regional mapping shapefiles (CPRM 2018). 
mining district (Dorr II 1969, Teixeira et al. 2017), as seen in Figure 2.

In Quadrilátero Ferrifero, the granite-gneiss complexes (Figs. 1 and 2) constitute continental blocks and juvenile arcs, crustally reworked since the Neoarchean (Lana et al. 2013, Albert et al. 2016, Farina et al. 2016). The tectonomagmatic events recorded in granitic complexes follow a protracted magmatic evolution between 3,220 and 2,600 Ma (Lana et al.2013, Albert et al. 2016, MartínezDopico et al. 2017).

The early magmatic pulse involves tonalite-trondhjemite-granodiorite emplacement in a large Paleoarchean crustal segment (> 3,200 Ma), which was partly reworked or recycled

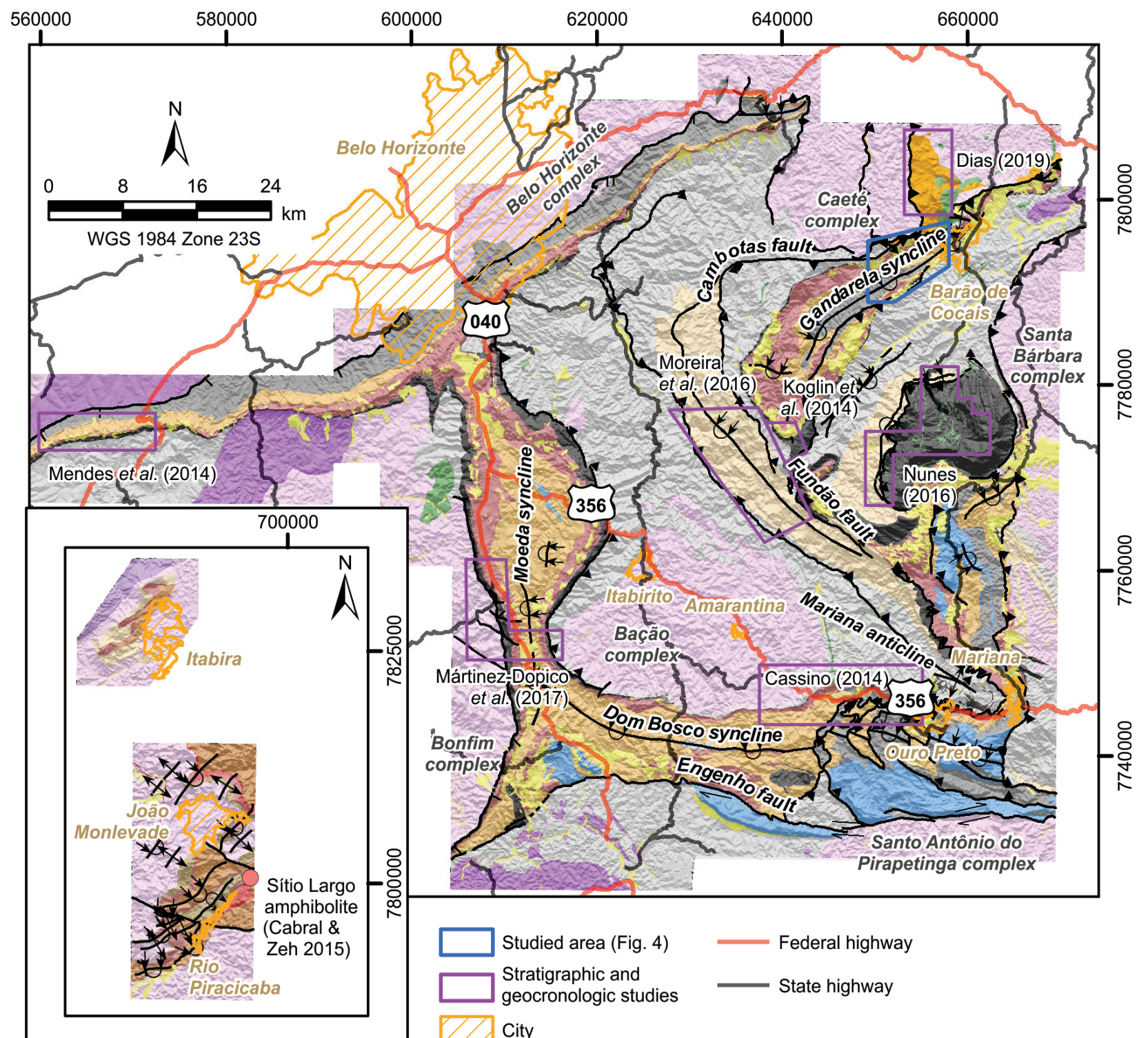

Lithostratigraphy

$\square$ Cenozoic cover

Intrusion suite

$\square$ Rhyacian amphibolite
$\square$ Proterozoic metamafic rock
$\square$ Neoarchean and Rhyacian granitoid rock

Paleoproterozoic

Statherian

Tamanduá Group: metasandstone and metaconglomerate

Rhyacian

Itacolomi Group: metasandstone and metaconglomerate
Piracicaba Group: metasandstone, metaconglomerate, metapelite and marble Siderian Itabira Group: itabirite and marble

Archean

Neoarchean

Caraça Group: metaconglomerate metasandstone and metapelite

RIO DAS VELHAS SUPERGROUP

Maquiné Group: metaconglomerate
and metasandstone
Nova Lima Group: metasandstone,
metapelite, metabasalt and metakomatiite
Paleo- to Neoarchean
$\square$ Granite-gneiss complex

Tectonic settings

$\leftrightharpoons$ Shear fault $\uparrow$ Anticline fold $\downarrow \downarrow$ Overturned syncline fold - Fault

$\stackrel{+}{+}$ Syncline fold

$\downarrow \downarrow$ Overturned anticline fold

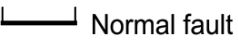

A Thrust fault

MINAS SUPERGROUP

Sabará Group: metadiamictite, metaconglomerate,

metasandstone and metasiltstone

Figure 2. Geological map of Quadrilátero Ferrífero (based on Lobato et al. 2005). 
during subsequent tectonic denudation and magmatic activities (Lana et al. 2013). The early activities constitute the Santa Bárbara event (3,220-3,200 Ma) recorded in the eastern part of Quadrilátero Ferrífero (Fig. 2) in granitic rocks of the Santa Bárbara complex and detrital zircon found in the supracrustal successions of this region, as well as in the inherited zircon populations of younger granitoid exposed around the Quadrilátero Ferrífero (Hartmann et al. 2006, Moreira et al. 2016, Farina et al. 2016, Martínez-Dopico et al. 2017).

Earlier studies by Lana et al. (2013) and Romano et al. (2013) suggested that the Santa Bárbara event was followed by three major magmatic ones that were responsible for $>90 \%$ of the granitic rocks exposed in Quadrilátero Ferrífero, i.e., the Rio das Velhas I (2,930-2,900 Ma), Rio das Velhas II (2,800-2,760 $\mathrm{Ma})$, Mamona I (2,750-2,700 Ma) and Mamona II (2,620$2,580 \mathrm{Ma}$ ) events. They seem to involve subduction of oceanic crust and subsequent continental collision and potassic magmatism (Farina et al. 2016). Likewise, recent investigations of the supracrustal sequence of Quadrilátero Ferrífero by Moreira et al. (2016) (Fig. 2) suggested that the continent collision was accompanied by felsic volcanism and turbiditic sedimentation of the Nova Lima Group (Rio das Velhas Supergroup base) and deposition of the continental clastic foreland deposits of Maquiné Group, top of the Rio das Velhas Supergroup (Machado et al. 1996, Noce et al.2005, 2007, Hartmann et al.2006, Farina et al. 2016, Martínez-Dopico et al. 2017).

During the waning stages of the potassic magmatism, Southern São Francisco crust experienced a rifting that was followed by the development of a passive margin after ca. 2,600 Ma (e.g.,
Hartmann et al. 2006, Martínez-Dopico et al. 2017). It marks the Minas Supergroup deposition, which comprises a ca. 8,000 $\mathrm{m}$-thick succession of continental to marine and syn-orogenic sedimentary rocks deposited from 2,580 to 2,100 Ma (Figs. 2 and 3) (Dorr II 1969, Renger et al. 1995, Alkmim \& Martins-Neto 2012, Martinez-Dopico et al. 2017). The Caraça Group comprises the rift-related sedimentary rocks of Moeda Formation that grade into marine deposits of the Batatal Formation. The Moeda Formation includes polymictic metaconglomerate with layers of medium- to coarse-grained metasandstone, phyllite, and fine-grained metaconglomerate (Villaça 1981). The depositional environment is interpreted as alluvial to deltaic with some marine influence (Villaça 1981) developed during the tectonically active phase (Renger et al. 1995). U-Pb detrital zircon ages from Moeda Formation point to Neoarchean sedimentation (Machado et al. 1996, Hartmann et al. 2006, Neri et al. 2013, Koglin et al.2014, Cassino 2014, Nunes 2016), with the youngest dated at 2,520 $\pm 13 \mathrm{Ma}$ (Nunes 2016), as in Figures 2 and 3. The overlaying Batatal Formation comprises sericite-phyllite containing iron-formation, chert, graphitic phyllite, and dolomite lenses (Alkmim \& Marshak 1998).

The chemical units from the younger Itabira Group and the metasedimentary rocks from the Piracicaba Group record the evolution from the marine to the deltaic depositional systems of the Minas basin (Dorr II 1969). Cauê Formation consists of Lake Superior-type itabirite (metamorphic-banded iron formation), ferruginous dolomite, and phyllite. The depositional age (DA) of Cauê Formation was conservatively interpreted between the maximum deposition ages from the top

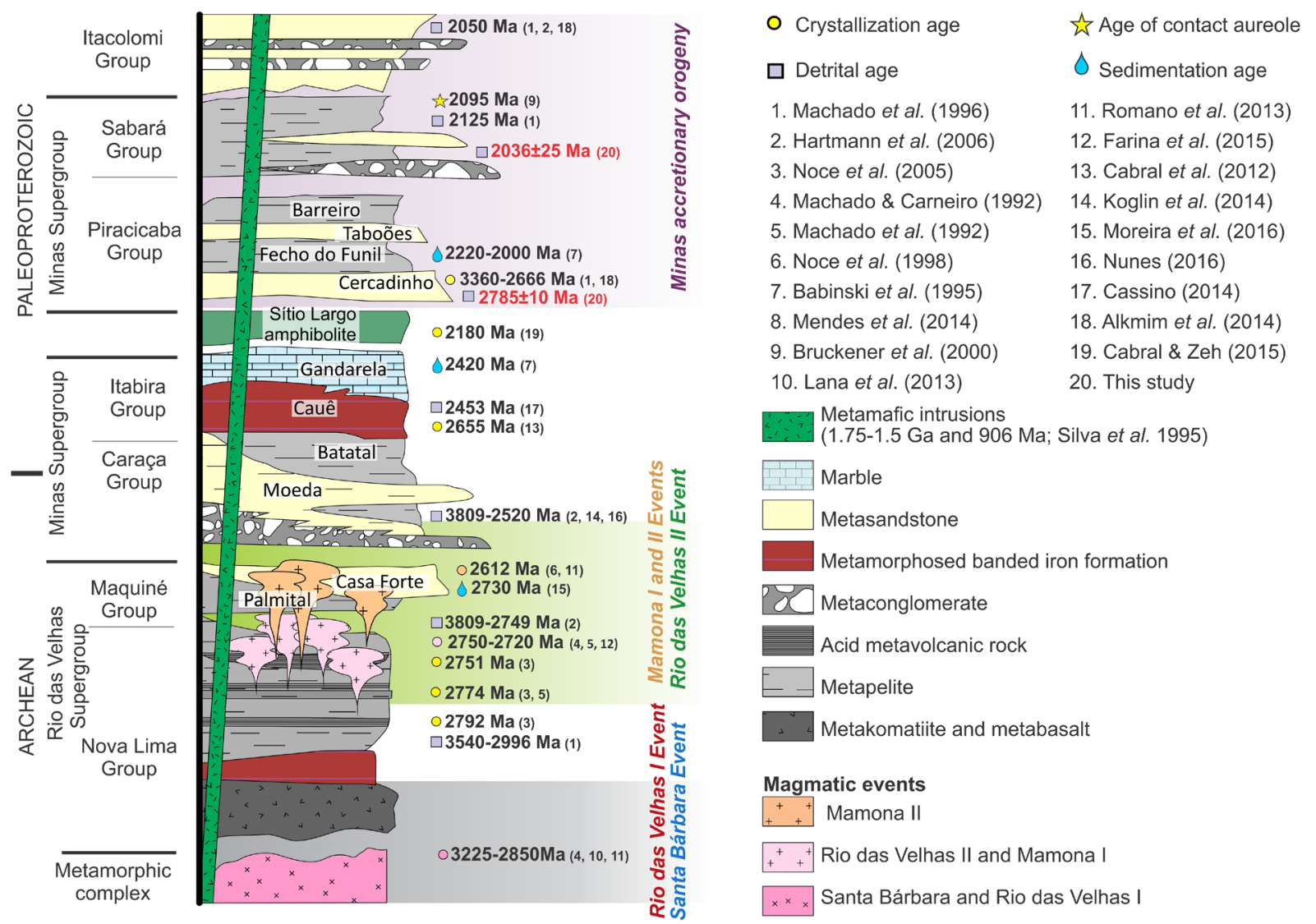

Figure 3. Stratigraphic column with available age and tectonic events from Archean to Paleoproterozoic evolution in Quadrilátero Ferrífero (based on Martínez-Dopico et al. 2017). 
of the underlying Moeda Formation and the age of overlying Gandarela Formation, ca. 2,520 Ma (Nunes 2016) and 2,420 Ma (Babinski et al. 1995), respectively. Cassino (2014) reinforces this hypothesis with a maximum DA of $2,453 \pm 18 \mathrm{Ma}(99.98 \%$ concordance) for a ferruginous metasandstone lens intercalated with Cauê Formation. In contrast, Cabral et al. (2012) proposed a U-Pb zircon age of 2,655 $\pm 6 \mathrm{Ma}$ for a meta-volcanic layer, which occurs within the overlying Cauê Formation. This result is controversial since the zircon grain could be inherited (Koglin et al. 2014), and it contradicts most of the published geochronological data for the underlying Caraça Group (Farina et al. 2016, Martínez-Dopico et al. 2017). Gandarela Formation is made up of dolomitic marble, carbonaceous phyllite, and dolomitic iron-formation. Souza \& Müller (1984) describe stromatolitic structures in limestone locally in Gandarela syncline, and Moore (1969) reports coarse-grained breccia with dolomite fragments in a matrix of dolomite and iron oxide in the upper part of this formation. This stromatolitic limestone has been dated based on a $\mathrm{Pb}-\mathrm{Pb}$ isochron age at 2,420 $\pm 19 \mathrm{Ma}$ (Babinski et al. 1995).

Gandarela Formation is unconformably overlain by the Piracicaba Group that includes Cercadinho, Fecho do Funil, Taboões, and Barreiro formations (Dorr II 1969, Rosière \& Chemale Jr. 2000). It comprises a thick package of transgressive to regressive marine and deltaic sedimentary rocks metamorphosed under regional greenschist and local amphibolite facies (Dorr II 1969). The Cercadinho Formation consists of metasandstone with ferruginous lenses, phyllite and, locally, dolomitic marble lens and metaconglomerate with clasts of phyllite, itabirite, chert, vein quartz that are mainly derived from Itabira Group and metasandstone fragments of indeterminate origin (Dorr II 1969). Mendes et al. (2014) (Fig. 2) attest to the significant sedimentary contribution of Meso- to Neoarchean sources, which average of the youngest cluster of zircon age is 2,680 \pm 24 Ma. The intermediate Fecho do Funil and Taboões formations are composed of phyllite, metasiltstone and impure dolomitic marble and fine-grained ortho-metasandstone, respectively. Equigranular metasandstone and graphitic phyllite of Barreiro Formation occupy the upper portion of the Piracicaba Group. The $\delta^{13} \mathrm{C}$ values suggest that Cercadinho carbonates were deposited during the early stage of a global biogeochemical anomaly at ca. 2.22 to $2.10 \mathrm{Ga}$, followed by the Fecho do Funil Formation (Bekker et al. 2003). This event occurred shortly after the end of the Paleoproterozoic glacial epoch (2.45-2.22 Ga). Babinski et al. (1995) proposed a $\mathrm{Pb}-\mathrm{Pb}$ isochron age of 2,110 $\pm 19 \mathrm{Ma}$, which is interpreted as the minimum deposition age of Fecho do Funil Formation. The unconformity between the Gandarela and Cercadinho formations could be the reason for the absence of geological and geochemical traces of this glaciation (Bekker et al. 2003). Locally, the unconformity is marked by the Sítio Largo amphibolite of $2.18 \mathrm{Ga}$ (Cabral \& Zeh 2015), exposed in Monlevade and Rio Piracicaba quadrangles (Reeves 1966) in the northeastern most portion of Quadrilátero Ferrífero, near the cities of João Monlevade and Rio Piracicaba (Figs. 2 and 3).

A regional unconformity separates the Minas basin sequences and the upper Sabará Group. Metadiamictite, metaconglomerate, metasandstone and metasiltstone constitute this group
(Dorr II 1969, Reis et al. 2002). Its deposition is interpreted as being syn-tectonic and reworked from the supracrustal units, granitic complexes and the collisional magmatic arc in a foreland system during the Rhyacian-Orosirian periods (Machado et al. 1992, 1996, Reis et al. 2002, Hartmann et al. 2006, Alkmim \& Martins-Neto 2012).

The Itacolomi Group exposed in southeast Quadrilátero Ferrífero (Figs. 2 and 3) overlies the Sabará Group uncomfortably. It comprises an up to $1,800 \mathrm{~m}$-thick fluvial sequence with a local marine transition (Alkmim 1987). Metasandstone, metaconglomerate, and minor metapelite were deposited during the collapse phase of the Rhyacian-Orosirian age orogen (Dorr II 1969, Alkmim \& Marshak 1998, Alkmim \& Martins-Neto 2012). Itacolomi sandstone indicates similar maximum DAs of 2,059 \pm $58 \mathrm{Ma}$ (Machado et al. 1996) and2,058 $\pm 9 \mathrm{Ma}$ (Alkmim et al.2014).

The Tamanduá Group encompasses polymictic metaconglomerate and metasandstone that grades laterally and upward into metasandstone interbedded with metarkose and, as upper rocks, phyllite and sericite metasandstone (Simmons 1968, Moore 1969, Crocco-Rodrigues 1991, Gomes 2017). A complete study in Cambotas ridge is summarized by Dias (2019) and indicates a Paleo- to Mesoproterozoic DA for Tamanduá Group (Fig. 2) (Dutra 2017, Dias 2019).

Quadrilátero Ferrífero was affected by two superimposed orogens during the Rhyacian-Orosirian periods and the Neoproterozoic to Early Ordovician. The main tectonic features in this region were attributed to Rhyacian-Orosirian progressive compressional deformation, which involved this region in a fold-thrust belt developed by the collision of the São Francisco paleoplate nucleus with other terrenes, and ultimately with the Congo paleoplate nucleus at ca. 2,100 Ma or immediately after it. This collision resulted in the development of northwest-verging regional folds, thrust faults, and shear zones. The metamorphic climax was probably reached at ca. 2,080-2,020 Ma (Sanglard et al. 2014, Teixeira et al. 2015, Farina et al. 2016, Aguilar et al. 2017). This tectonomagmatic event $(2,100-1,900 \mathrm{Ma})$ is usually referred to as Trans-Amazonian Cycle, a designation introduced by Hurley et al. (1967) to an orogeny at East Amazonian and West African craton, but, as argued by Brito-Neves (2011), the "Trans-Amazonian" term should be abandoned due to its indiscriminate use. We followed this recommendation and adopted "Minas accretionary orogeny", which is a term proposed by Teixeira et al. (2015) referring to the Rhyacian-Orosirian deformation/metamorphism at the southern São Francisco craton. The Neoproterozoic to Early Ordovician Brasiliano event (700-450 Ma) overprints and reactivates the Archean and Paleoproterozoic structures by a series of W-verging thrust fault (Endo \& Machado 2002). This event is responsible for the development of shear zones in the border of granitic domes and strike-slip faults associated with greenschist-facies metamorphism (Alkmim \& Marshak 1998).

\section{METHODOLOGY}

Our detailed stratigraphic study was based on 1:100,000 geologic mapping in the region nearby Barão de Cocais, in the northeast of Quadrilátero Ferrífero (Figs. 2 and 4). 
Four stratigraphic sections, perpendicular to the strike of layers, were performed in the north (normal) and south (inverse) limb of Gandarela syncline (Fig. 4), and the geometries of bed, the nature of the contacts and the facies characteristics of the Cercadinho Formation (Piracicaba Group) and Sabará Group were described. These sections were logged at a scale of 1:100,

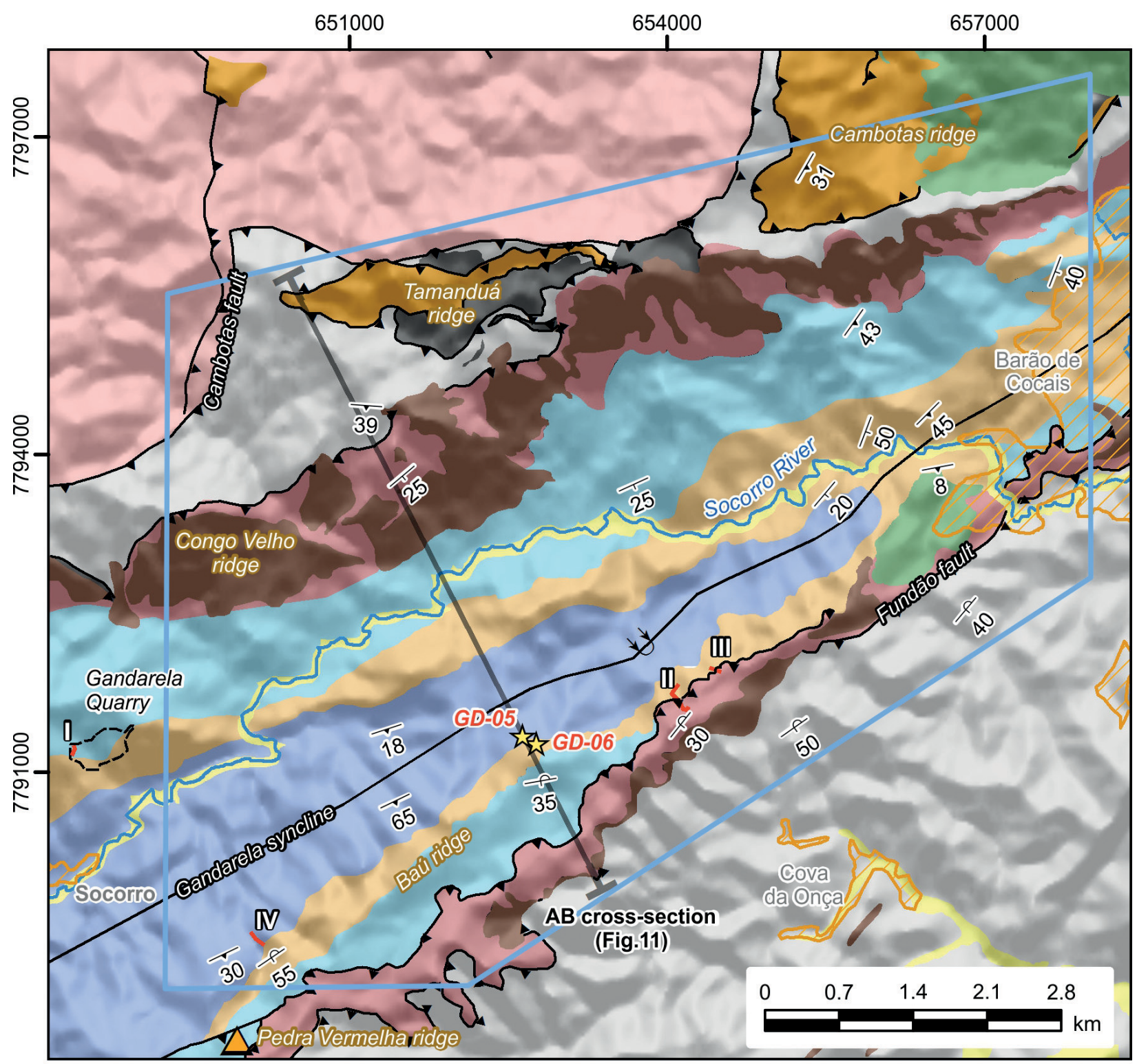

Lithostratigraphy

$\square$ Alluvium: sand, clay and gravel

Lateritic cover: iron-formation fragments cemented by limonite

$\square$ Tamanduá Group: metasandstone and polymictic metaconglomerate

Metamafic suit: metadiabase

Minas Supergroup

W Sabará Group: metapelite and metasandstone

Cercadinho Formation: metasandstone interbedded with metapelite

Piracicaba Group

Gandarela Formation: dolomitic marble

Cauê Formation: itabirite

Caraça Group: fine-grained sericite-metasandstone and metapelite Rio das Velhas Supergroup

$\square$ Nova Lima Group: phyllite, chlorite and sericite-quartz schist
诂 Samples locaties

Studied area

Main river

-_-_] Quarry

7 City

_ Stratigraphic section

\section{Structures}

__ Thrust fault

$\downarrow \downarrow$ Overturned syncline fold

1 Bedding

$\checkmark$ Overturned bedding

$\_$Schistosity

\section{Caeté Complex: granitic to granodioritic gneiss}

Figure 4. Geologic map of the northeastern part of the Gandarela Syncline (based on Lobato et al. 2005, Saraiva 2012, Katahira 2013, Dutra 2017). 
using Jacob's staff, Brunton-type compass-clinometer and measuring tap as proposed by Coe (2010). This aims to provide the characteristics of the stratigraphic architectures and depositional models from the upper units of Minas Supergroup.

Two samples (Figs. 4) were collected along the $A B$ cross-section in the Baú ridge and are representative of Cercadinho Formation (Piracicaba Group) and Sabará Group. About $15 \mathrm{~kg}$ of rocks for each sample (two) were collected for $\mathrm{U}-\mathrm{Pb}$ analyses of zircon grains, and the entire procedure was conducted in the Department of Geology of the Universidade Federal de Ouro Preto. The samples were crushed and pulverized with jaw crusher and grinder. The heavy mineral concentration was conducted through manual panning and, subsequently, magnetic methods. The non-magmatic zircon fraction was handpicked under a binocular microscope disregarding the color, shape, and size of the grains. The collected material was mounted in an epoxy mount (SpeciFix, $25 \mathrm{~mm}$ ). The entire preparation process was done in the Laboratory of Preparation of Geochronological Samples. After polishing the mounts, the zircon grains were imagined via cathodoluminescence (CL) in a JEOL 6510 Scanning Electron Microscope in the Microanalysis Laboratory.

Almost 120 zircon grains were analyzed from each sample in a ThermoScientific Element 2 sector field inductively coupled plasma mass spectrometry (SF-ICP-MS) coupled to a CETAC LSX-213 G2 + laser ablation system. Integration times were $15 \mathrm{~ms}$ for ${ }^{206} \mathrm{~Pb}$ and ${ }^{238} \mathrm{U}, 40 \mathrm{~ms}$ for ${ }^{207} \mathrm{~Pb}$ and $10 \mathrm{~ms}$ for ${ }^{208} \mathrm{~Pb},{ }^{204} \mathrm{~Pb}+{ }^{204} \mathrm{Hg}$ and ${ }^{232} \mathrm{Th}$. The laser spot size was $20 \mu \mathrm{m}$, and the repetition rate is $10 \mathrm{~Hz}$. Helium was used as a carrier gas mixed with argon prior to introduction into the ICP-MS. Individual spots were selected based on CL images of the samples, in order to avoid fractures, dark areas (U-rich) in the CL image and inclusions and connected internal textures.

Common $\mathrm{Pb}$, instrumental mass discrimination and laser-induced elemental fractionation of $\mathrm{Pb} / \mathrm{U}$ were corrected by normalizing $\mathrm{U} / \mathrm{Pb}$ and $\mathrm{Pb} / \mathrm{Pb}$ ratios of the sample zircons to the zircon standards and $\mathrm{Pb}$ composition, as proposed by Stacey \& Kramers (1975), to the reference zircon GJ-1 (Jackson et al. 2004) of each analytical session. Multiple analyses of the reference zircon BB (Santos et al. 2017) were performed during each session to test the validity of the applied method and the reproducibility of the obtained age data. The GJ-1 standard offered concordia age of 606.0 $\pm 4.8 \mathrm{Ma}(2 \sigma, n=40$; MSWD = 1.13), whereas the BB secondary standard provided concordia age of $563.3 \pm 4.8 \mathrm{Ma}$ $(2 \sigma, n=41$; MSWD $=1.3)$. The calculated ages are consistent within uncertainty with the ID-TIMS values reported for reference zircons by Jackson et al. (2004) and Santos et al. (2017), respectively.

The signal data were initially reduced using the software Glitter (van Achterbergh et al. 2001). Common Pb corrections were done off-line using interference and background-corrected ${ }^{204} \mathrm{~Pb}$ signals in combination with the $\mathrm{Pb}$ model composition of Stacey \& Kramers (1975). This is done with an in-house Excel spreadsheet that takes all mass-bias and drifts corrected counts exported from Glitter into account. The age distributions, concordia diagrams, and weighted mean ages were plotted and calculated with Isoplot 4.15 (Ludwig 2009).

The results of the LA-ICP-MS analyses for samples and reference zircons are reported in the supplementary data. The samples provided 267 zircons, in which 100 had a maximum discordance of $5 \%$. The diagrams are given by the ${ }^{207} \mathrm{~Pb} /{ }^{206} \mathrm{~Pb}$ ages, and all errors are displayed as two standard deviations $(2 \sigma)$.

The maximum DA is an important tool for stratigraphic correlation of a sedimentary unit devoid of fossiliferous content and/or volcanic units (Gehrels 2014). However, some uncertainties, when analyzing the U-Pb age of the detrital zircon grains, can result in misleading measures, such as the loss of radiogenic $\mathrm{Pb}, \mathrm{Th} / \mathrm{U}$ ratio, errors associated with the analysis method and inadequate number of data (Vermeesch 2004, Andersen 2005, Dickinson \& Gehrels 2009, Gehrels 2014, Pullen et al. 2014, Spencer et al. 2016). We follow the methodology of Dickinson \& Gehrels (2009), who proposed that the maximum deposition age can be evaluated by the weighted mean age or the age of the probability peak from the youngest cluster $(n \geq 3)$. Thus, the youngest single grain or the youngest cluster (with less than three concordant $\mathrm{U}-\mathrm{Pb}$ ages) were avoided in the DA estimation.

\section{FIELD OBSERVATIONS}

The study area is in the northeast segment of the Gandarela syncline, which extends for ca. $44 \mathrm{~km}$ in the north-northeast portion of the Quadrilátero Ferrífero (Fig. 4). This regional structure, formed during the Minas accretionary orogeny (Marshak \& Alkmim 1989, Fonseca et al. 2018), is an overturned syncline with moderately northeastward-plunging axis, vergence to north-northwest, which limbs accommodate system of faults and the southern one is inverted (Dorr II 1969, Endo \& Fonseca 1992, Chemale Jr. et al. 1994).

The lithostratigraphy of northeastern Gandarela syncline comprises granitic rocks of Caeté complex, metavolcanossedimentary rocks of the Nova Lima Group (Rio das Velhas Supergroup) and Minas Supergroup, and mafic suit(s) (Fig. 4). The Caeté Complex shows deeply weathered outcrops and is made up of granitic to granodioritic gneiss (Brandalise \& Heineck 1999).

The Nova Lima Group encompasses phyllite, chlorite, and sericite-quartz schist (Fig. 5A and B). Fresh exposures are very sparse and, mainly, the outcrops are deeply weathered and covered by clayey soil (Fig. 5A and B). Its contacts with the Minas Supergroup are defined by reverse faults.

Moeda Formation (Caraça Group) is represented by finegrained sericite-metasandstone with locally dispersed pebbles. Batatal Formation (Caraça Group) is composed of sericite metapelite and commonly covers Moeda Formation though a normal contact. Cauê Formation (Itabira Group) is made up of itabirite. Gandarela Formation (Itabira Group) is mainly represented by dolomite (Fig. 5C) with metapelite lenses towards the unit top. The Itabira Group overlies the Nova Lima Group through the Fundão-Cambotas fault system (Endo \& Fonseca 1992), and its contact with the upper Cercadinho Formation (Piracicaba Group) is marked by erosive and angular boundaries. 
The Piracicaba Group is only represented by Cercadinho Formation, which is composed of a heterogeneous package of fine- to medium-grained metasandstone (Fig. 5D) interbedded with metapelite. The Sabará Group comprises black, purple and pale-yellow metapelites (Fig. 5E), whose color is a consequence to the mineralogical composition variation, such as chlorite, ferromagnesian oxides, and sericite. In places, it is intercalated with fine-grained metasandstone and quartzpebble-rich layers. Its contact with Cercadinho Formation is marked by an angular unconformity.

The Tamanduá Group comprises fine- to medium-grained metasandstone and polymictic metaconglomerate with fine- to
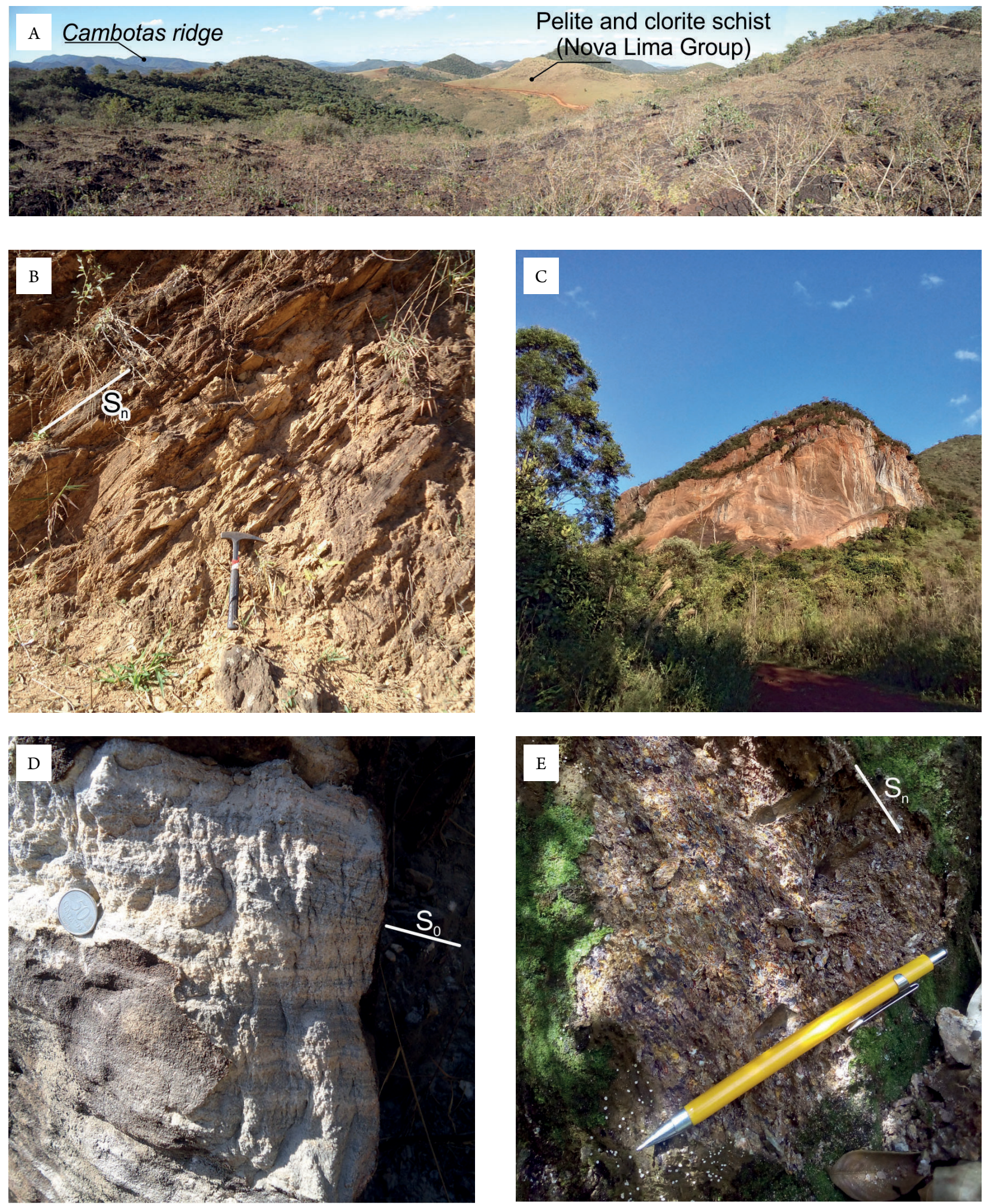

Figure 5. (A) General morphology of the southern portion of the study area with rocks of the Nova Lima Group (Rio das Velhas Supergroup) and the lateritic cover overlying the Cauê itabirites. View to the East (654647/7791835, WGS 1984 Zone 23S). (B) Sericite schist typical of the Nova Lima Group with well-marked schistosity S $_{\mathrm{n}}$. Photo with a Southwestern view (657348/7793319, WGS 1984 Zone 23S). (C) Pedra Vermelha ridge with dolomite of Gandarela Formation. Photo with a view to the South (649392/7788581, WGS 1984 Zone 23S). (D) Metasandstone with bands of ferruginous minerals marking sedimentary bedding $S_{0}$ of Cercadinho Formation (view from E, coin diameter: $\left.23 \mathrm{~mm}\right)(654432 / 7792022$, WGS 1984 Zone 23S). (E) Metapelite of the Sabará Group, photo with a view to the SW (649268/7788866, WGS 1984 Zone 23S). 
coarse-grained matrix and centimetric pebbles of itabirite and quartz. This unit outcrops in the north limb of Gandarela syncline, Tamanduá ridge, and Cambotas ridge that its only southmost portion is present in the study area (Figs. 4 and 5).

The meta-igneous rock occurs in stock intrusion in the Cauê and Cercadinho formations and in the eastern portion of Cambotas ridge. The outcrops are mostly weathered to eutroferric red latosol as near the city Barão de Cocais (Fig. 4), but in the few fresh outcrops that can be found are of metadiabase. This rock was dated at $906 \pm 2 \mathrm{Ma}$ (Silva et al. 1995). The Cenozoic covers are made up of alluvium (sand, clay and gravel) nearby Socorro river and lateritic cover, which is developed above the itabirite of Cauê Formation (Figs. 4 and 5A).

\section{FACIES DESCRIPTION AND DEPOSITIONAL SYSTEMS}

The detailed stratigraphic analysis (1:100) of Piracicaba and Sabará groups shows a rhythmic association between massive or poorly stratified metasandstone and metapelite, being associated with high- to low-density turbidity currents. It was separated into five facies (Tab. 1) based on the sedimentary characteristics, such as composition, grain size, texture, sedimentary structures, and body geometry. The geometry of each metasandstone and metapelite bed is tabular and laterally amalgamated in both successions.

Cercadinho Formation is made up of massive metasandstone (FB, FC and FD facies) and metapelite (FE facies). The metasandstone shows massive texture and, locally, coarsegrained layers, with poor (FB and FC facies) to well (FD facies) sorted and sub-rounded to sub-angular quartz with ferruginous minerals. The individual bed thickness ranges from 0.5 to $10.0 \mathrm{~m}$. The metapelite (FE facies) shows a thickness of 0.2$3.2 \mathrm{~m}$, it is interbedded with metasandstone in the Congo Velho ridge (Fig. 6) and occurs in the top of Cercadinho Formation sections in the Baú ridge (Fig. 7). The contacts between the metasandstone and metapelite are commonly sharp and non-erosive, but locally they are erosive (Fig. 8), whereas the contacts between the metasandstone facies (FB, FC and FD) are gradational and, locally, abrupt (Fig. 7). The sections show a rhythmic association between massive or poorly stratified metasandstone and a fining-upward facies cycle marked by a progressive grain-size reduction in the metasandstone with increase in the content of muddy layers.

Our stratigraphic section of Sabará Group (Figs. 9 and 10) near Pedra Vermelha ridge indicates predominance of metapelite packages over metasandstone bodies. The succession sequence shows the FA, FC, and FE facies. The metapelite (FE facies) shows massive texture and, locally, laminated stratification. Its thickness reaches $15 \mathrm{~m}$. The metasandstone beds are represented by a pebbly metasandstone (FA facies) and medium-grained laminated metasandstone (FC facies). The pebbly metasandstone (FA facies) shows angular to sub-rounded clasts that range from granule to pebble of quartz and smoky quartz in a fine sandy matrix, which are oriented parallel to the bedding $\mathrm{S}_{0}$ and schistosity $\mathrm{S}_{\mathrm{n}}$. This facies shows inverse-to-normal grading patterns indicated by the increase and decrease of clast percent towards the top of bodies. The medium-grained laminated metasandstone (FC facies) occurs, locally, with massive texture, moderately sorted and sub-rounded to sub-angular quartz grain. Its thickness ranges from 5.0 to $50.0 \mathrm{~cm}$. The contacts of metasandstone bodies are sharp and non-erosive or gradational as in the FA facies. The pebbly metasandstone interbedded with the metapelite indicates the depositional energy change. The stratigraphy framework of this section suggests coarsening- and fining-upward facies succession.

The facies succession of Cercadinho Formation and Sabará Group are attributes to mass flow processes (see Shanmugam 2016) as indicated by bed geometry and facies characteristics. The pebbly and coarse- to medium-grained metasandstone (FA

Table 1. Facies of Cercadinho Formation (Piracicaba Group) and Sabará Group in the Gandarela syncline.

\begin{tabular}{|c|c|c|c|}
\hline Facies & Lithology & Description & Sedimentary processes \\
\hline $\mathrm{FE}$ & Massive metapelite & $\begin{array}{l}\text { Massive metapelite with thickness ranges } \\
\text { from } 0.08 \text { to } 3.20 \mathrm{~m} \text {, which occurs in all } \\
\text { extension of the studied successions }\end{array}$ & $\begin{array}{l}\text { Precipitation from suspension turbidite flow and low- } \\
\text { density turbidity currents (Lowe 1982, Mutti 1992, } \\
\text { Mulder et al. 2003, Zavala et al. 2011, Zavala \& Arcuri } \\
\text { 2016). The facies is based on the F9 of Mutti (1992) } \\
\text { and Mutti et al. (2003) }\end{array}$ \\
\hline FD & $\begin{array}{l}\text { Massive } \\
\text { metasandstone }\end{array}$ & $\begin{array}{l}\text { Fine-grained metasandstone from } 0.2 \text { to } \\
18 \mathrm{~m} \text { mostly described in the upper portion } \\
\text { of Cercadinho Formation sections and } \\
\text { always associated with the FC facies }\end{array}$ & $\begin{array}{l}\text { Low-density turbidity currents (Lowe 1982). } \\
\text { The facies is based on the F8 of Mutti et al. (2003) }\end{array}$ \\
\hline FC & $\begin{array}{c}\text { Laminated } \\
\text { metasandstone }\end{array}$ & $\begin{array}{l}\text { Medium-grained laminated metasandstone } \\
\text { with locally massive texture. The thickness } \\
\text { ranges from } 0.5 \text { to } 3.0 \mathrm{~m}\end{array}$ & $\begin{array}{l}\text { Low-density turbidity currents (Lowe 1982). } \\
\text { The facies is based on the F8 of Mutti et al. (2003) }\end{array}$ \\
\hline FB & $\begin{array}{c}\text { Massive } \\
\text { metasandstone }\end{array}$ & $\begin{array}{l}\text { Poorly sorted, coarse-grained metasandstone } \\
\text { beds with subordinate interbedded muddy- } \\
\text { rich lenses, which are well characterized at } \\
\text { the base of the studied strata. Their thickness } \\
\text { range from } 0.15 \text { to } 2.0 \mathrm{~m}\end{array}$ & $\begin{array}{c}\text { High- to low-density turbidity currents } \\
\text { (Lowe 1982, Mutti 1992). The facies is based on } \\
\text { the F7 of Mutti et al. (2003) }\end{array}$ \\
\hline FA & $\begin{array}{l}\text { Pebbly } \\
\text { metasandstone }\end{array}$ & $\begin{array}{c}\text { Metasandstone bodies from } 2.0 \text { to } 5.0 \mathrm{~m} \\
\text { with angular to sub-rounded quartz } \\
\text { pebbles. This facies is exclusive of } \\
\text { Sabará Group }\end{array}$ & $\begin{array}{l}\text { High-density turbidity currents (Lowe 1982, Mutti } \\
\text { 1992, Stow \& Johansson 2000, Bass 2004) }\end{array}$ \\
\hline
\end{tabular}


and FB facies) represents high concentrations of grains, which were quickly deposited under the deceleration of turbidity currents (Stow \& Johansson 2000). The FA facies records a progressive strength loss of the flow that resulted in inverse grading (Mutti 1992), followed by a temporal flow deceleration that formed the normal grading (Bass 2004). The FB and FD facies can be interpreted as F7 facies of Mutti et al. (2003), which is related to sand lobes accumulated in the mid-fan zone by turbulent flows associated with a near-bed suspension (i.e., a dense flow formed by turbulent mixing at the leading edge of basal turbidity flow during its motion) (Mutti et al. 1999, 2003). The stages of flow deceleration are recorded through $\mathrm{FC}$ and $\mathrm{FH}$ facies, which is consistent with F8 and F9 facies of Mutti et al. (2003), respectively. The muddy and fine sandy grains are incorporated as suspended load in the upper turbulent flow and deposited by a waning sediment flow across the shelf and slope (Mulder et al. 2003, Zavala \& Arcuri 2016) and by fallout processes (Lowe 1982, Mutti 1992, Zavala et al.2011) in the ocean or lake.
Thus, the Cercadinho Formation is interpreted as highto low-density turbidity successions (Lowe 1982, Bass 2004, Haughton et al. 2009), and the Sabará Group representation is mostly a low-density turbidity sequence with a temporal increase of the energy flow (Mutti 1992, Bass 2004) indicated by FA facies (pebbly metasandstone).

\section{RESULTS OF U-Pb ANALYSIS}

The zircon grains are mostly subhedral and rounded and, in some cases, they are fractured. Their size varies between 80 and $250 \mu \mathrm{m}$. The grains might be massive or show internal oscillatory zoning, and there is no clear relationship between $\mathrm{CL}$ images and $\mathrm{U}-\mathrm{Pb}$ ages.

The GD-06 sample (Cercadinho Formation, UTM: 652631/7791340, WGS 1984 Zone 23S) was collected in a fine-grained metasandstone (FD facies) with ferruginous lenses in the top of Cercadinho Formation (Fig. 11). In this

Stratigraphic section I: Congo Velho ridge
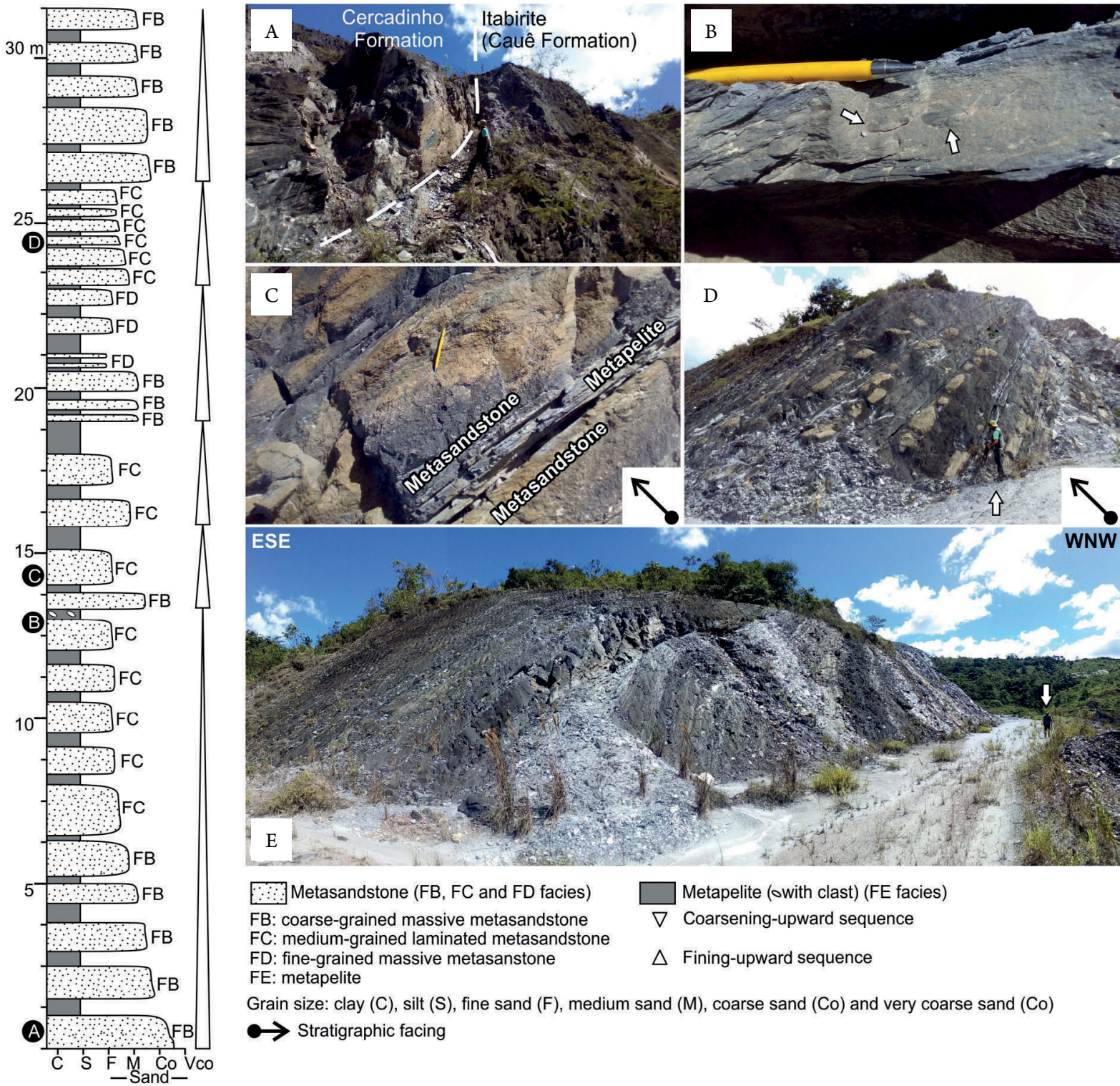

Metasandstone (FB, FC and FD facies)

FB: coarse-grained massive metasandstone FC: medium-grained laminated metasandstone FD: fine-grained massive metasanstone FE: metapelite

Grain size: clay $(C)$, silt $(S)$, fine sand $(F)$, medium sand $(M)$, coarse sand $(C o)$ and very coarse sand (Co)

$\rightarrow$ Stratigraphic facing

Figure 6. Stratigraphic $\log$ I of Cercadinho Formation near the district of Socorro (the normal limb of Gandarela syncline; view from E, pencil length: $15 \mathrm{~cm}$ ). (A) Tectonic contact between the Cercadinho metasedimentary rocks and the itabirite of Cauê Formation (Itabira Group). (B) Elliptical clasts in metapelite. (C) and (D) Medium-grained metasandstone interbedded with metapelite. (E) Partial view of Cercadinho strata showed. 
portion, sedimentary structures were not preserved. The zircon color ranges from translucent to brown and they are mostly subhedral, but some grains have smoothed corners and a few edges (Fig. 12). The prevailing grain size is $100-250 \mu \mathrm{m}$. The age distribution is broad (Fig. 13), spanning from 3,347 Ma to 2,561 Ma. The main populations are Mesoarchean
$(3,189-2,804 \mathrm{Ma}, n=12)$ and Paleoarchean $(3,347-3,228$ Ma, $n=6$ ). The tectonomagmatic events, Santa Bárbara (ca. 3,293-3,228 Ma, $n=5)$ and Rio das Velhas II (2796-2781 Ma, $n=3$ ), are marked by the secondary populations. The oldest U-Pb age predates the Santa Bárbara event, 3,347 \pm 19 $\mathrm{Ma}(100 \%$ concordance $)$.

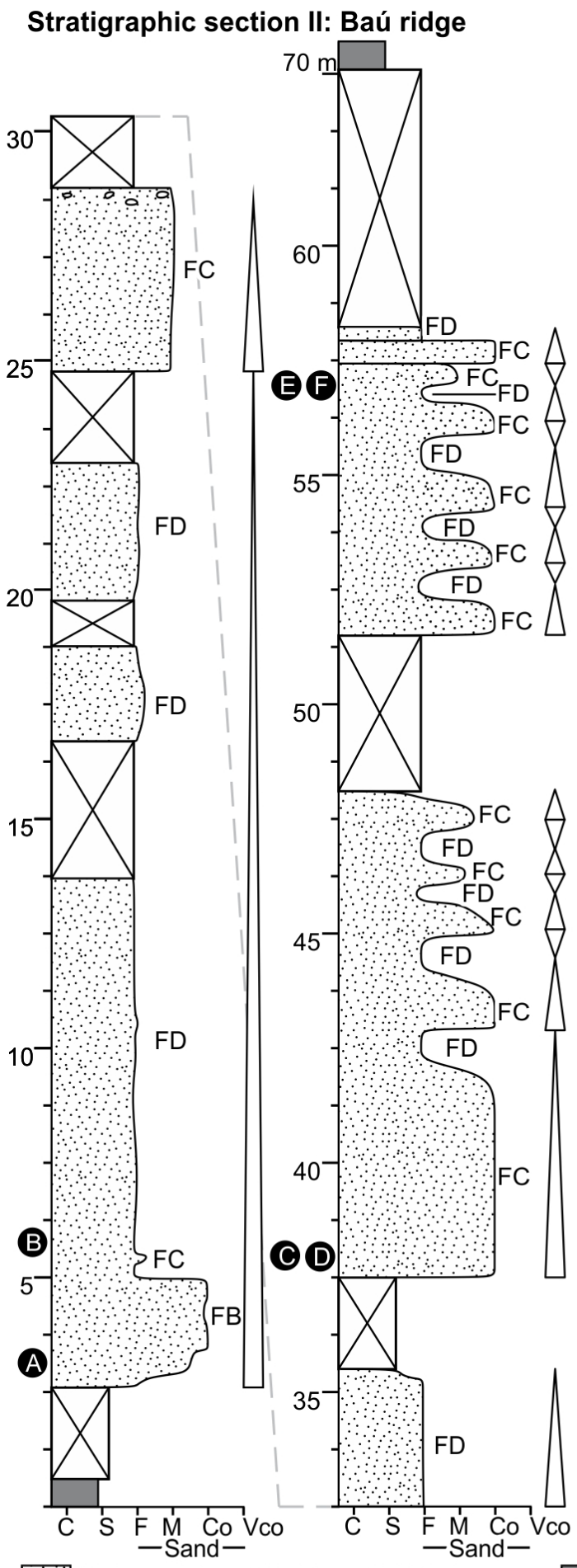

Stratigraphic section III: Baú ridge

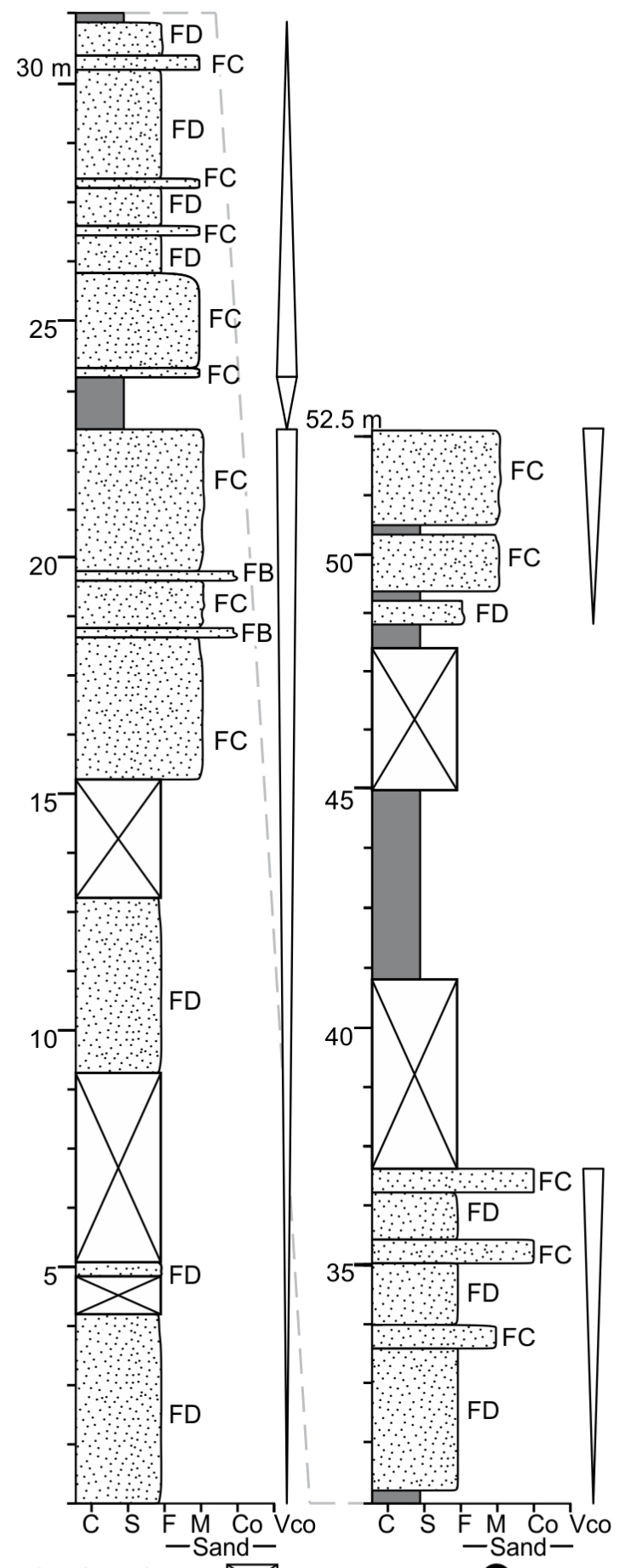

$\therefore$ Metasandstone (FB, FC and FD facies)

FB: coarse-grained massive metasandstone

FC: medium-grained laminated metasandstone

FD: fine-grained massive metasanstone

FE: metapelite

Grain size: clay $(C)$, silt $(S)$, fine sand $(F)$, medium sand $(M)$, coarse sand $(C o)$ and very coarse sand (Co)

Figure 7. Stratigraphic sections II and III of Cercadinho Formation in Baú ridge, the inverse limb of Gandarela syncline. 
The GD-05 sample (654147/7791724, WGS 1984 Zone 23S) was extracted from a chlorite metapelite (FE facies) at the base of Sabará Group, near the contact with the Cercadinho Formation and the GD-06 sample point (Fig. 11). Most zircon grains are completely round, and the main mode is $80-100 \mu \mathrm{m}$
(Fig. 12). The GD-05 presents two main populations: 2,968$2,485 \mathrm{Ma}(n=33)$ and 2,286-1,929 Ma $(n=42)$ (Fig. 13). The most characteristic population is related to the Minas accretionary orogeny $(2,231-1,929 \mathrm{Ma}, n=37)$ followed by the population of the Archean tectonomagmatic event, Rio das
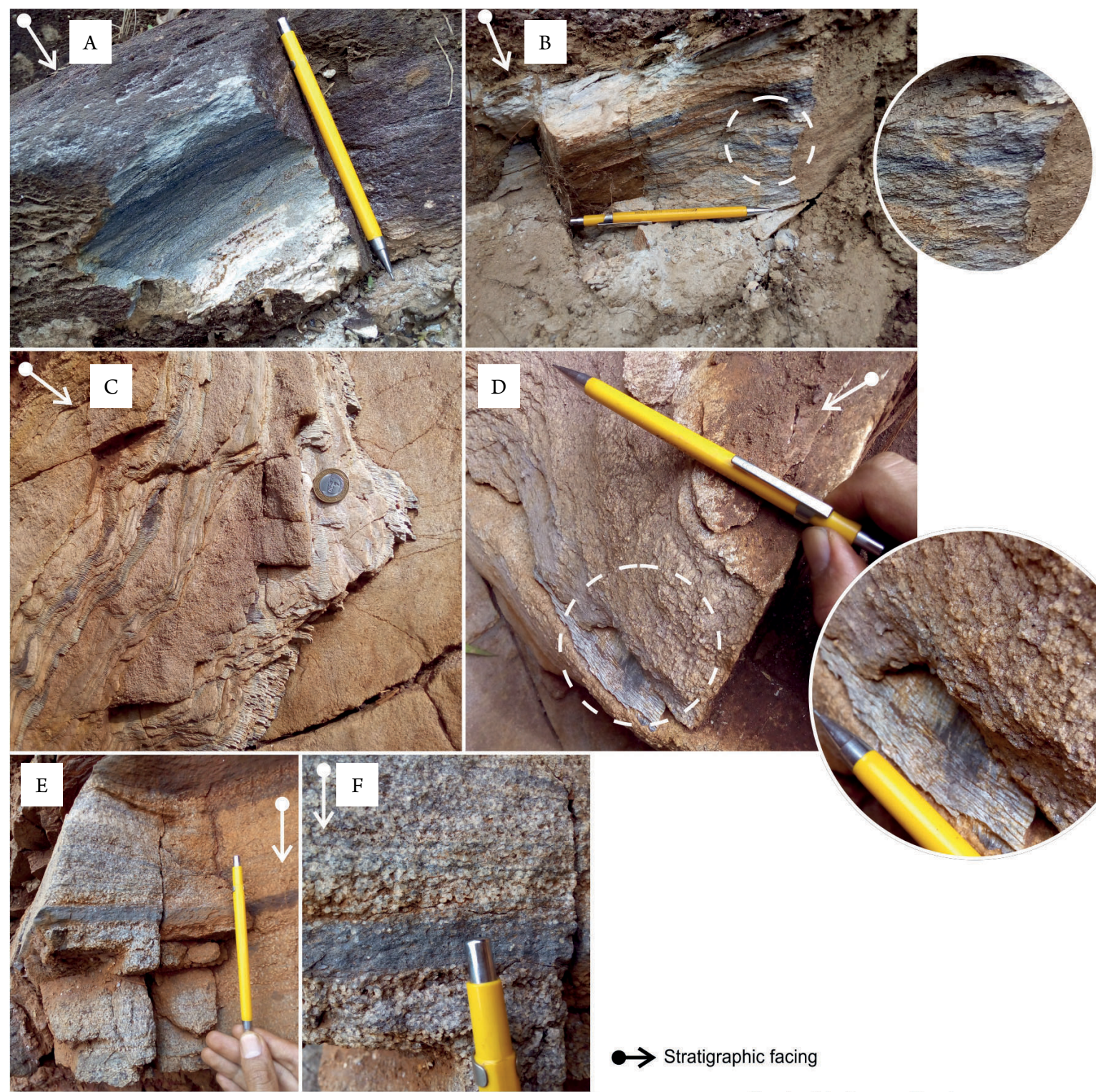

$\longrightarrow$ Stratigraphic facing

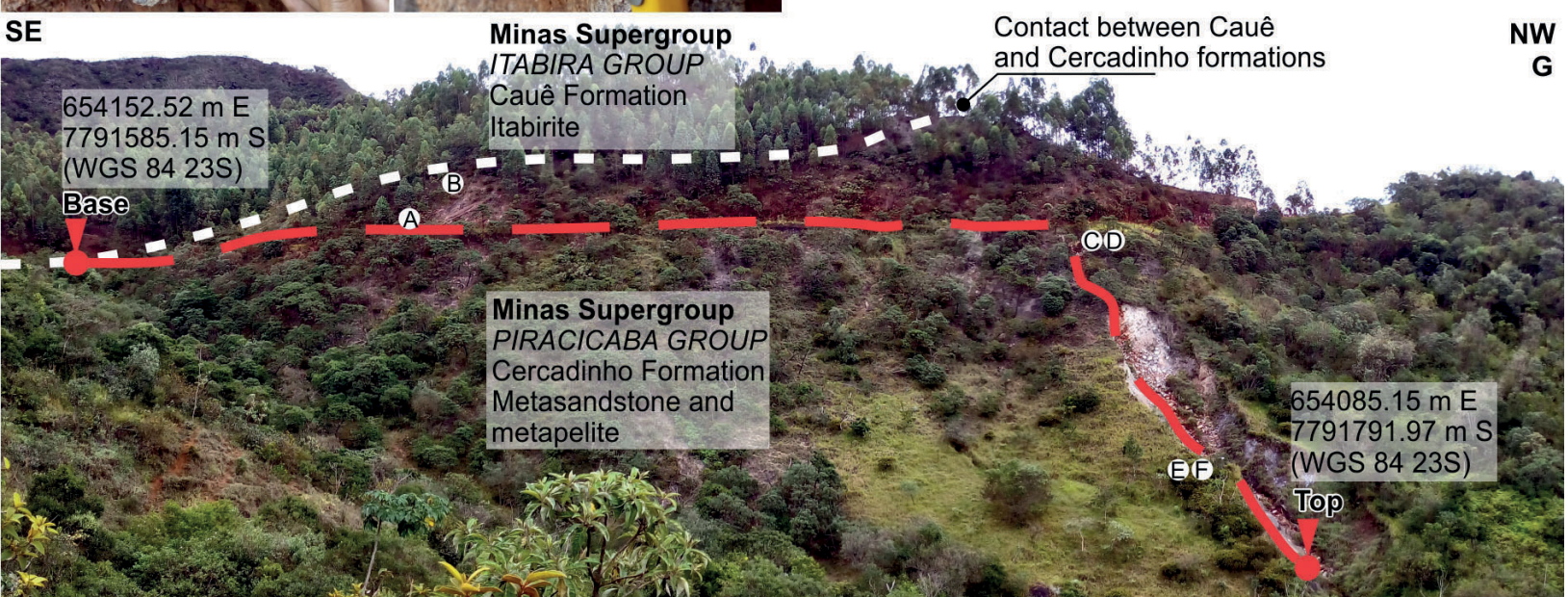

Figure 8. Photos of stratigraphic log II (the inverse limb of Gandarela syncline; pencil: $15 \mathrm{~cm}$; view from the southwest). (A) Medium to fine-grained metasandstone (bedding $S_{0}$ is parallel with schistosity $S_{n}$ ). (B) Fine-grained metasandstone with gray, white and straw yellow layering marking the bedding $\mathrm{S}_{0}$. (C) Metasandstone with metapelite intercalations (coin: $2.4 \mathrm{~cm}$ ). (D) Thickness variation of metapelite and metasandstone. (E) and (F) Coarse-grained metasandstone interlayered with metapelite with some quartz in the basal portion. (G) Path of the stratigraphic section II (dashed-red line). 
Velhas II (2,793-2,772 Ma, $n=5)$. Populations of 2,623-2,485 $\mathrm{Ma}(n=4)$ and 3,059-2,967 Ma $(n=3)$ do not correlate with a specific tectonomagmatic event known in the eastern São Francisco craton. The Paleoarchean zircon of $3,335 \pm 16 \mathrm{Ma}$ (98.5\% concordance) represents the oldest $\mathrm{U}-\mathrm{Pb}$ age in this sample and is prior to the Santa Bárbara event.

\section{DISCUSSION}

The detailed stratigraphic research and mapping work of Cercadinho Formation indicate that it was deposited through high- to low-density turbidity currents, which could be associated with the tectonic activity (Bouma 2000, Mattern 2005). This interpretation can be linked to rivers whose sediments are funneled through submarine canyons to submarine fans (Bouma 2000, Mattern 2005). When the sediments reach the coastline, they can form a deltaic system (Bouma 2000), as it is generally associated with the deposition environment of Cercadinho Formation (Dorr II 1969, Renger et al. 1995). Moraes (1985) supports this scenario for Cercadinho Formation and describes the unit in the southeast Quadrilátero Ferrifero as a result of (i) delta front sedimentation (coarse- to medium-grained metasandstone with
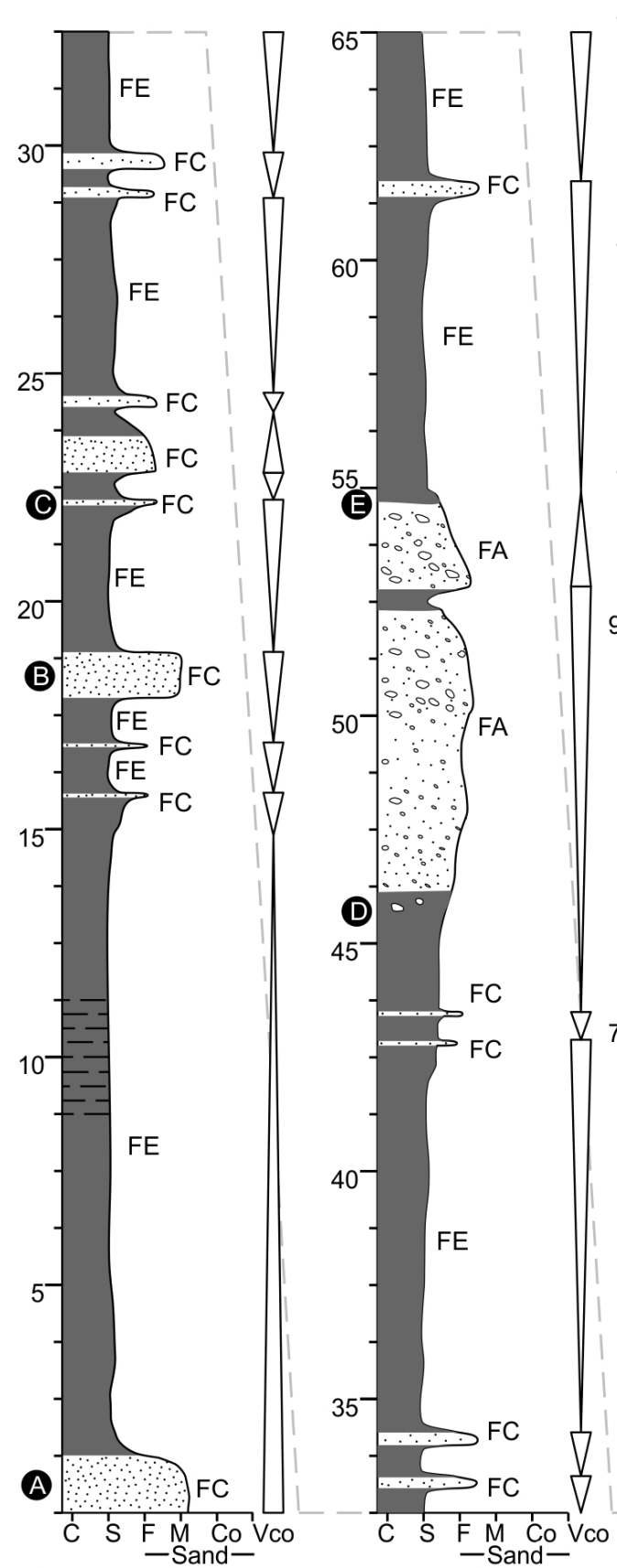

Metasandstone (FA and FD facies)

FA: pebbly metasandstone

FC: medium-grained laminated metasandstone FE: metapelite

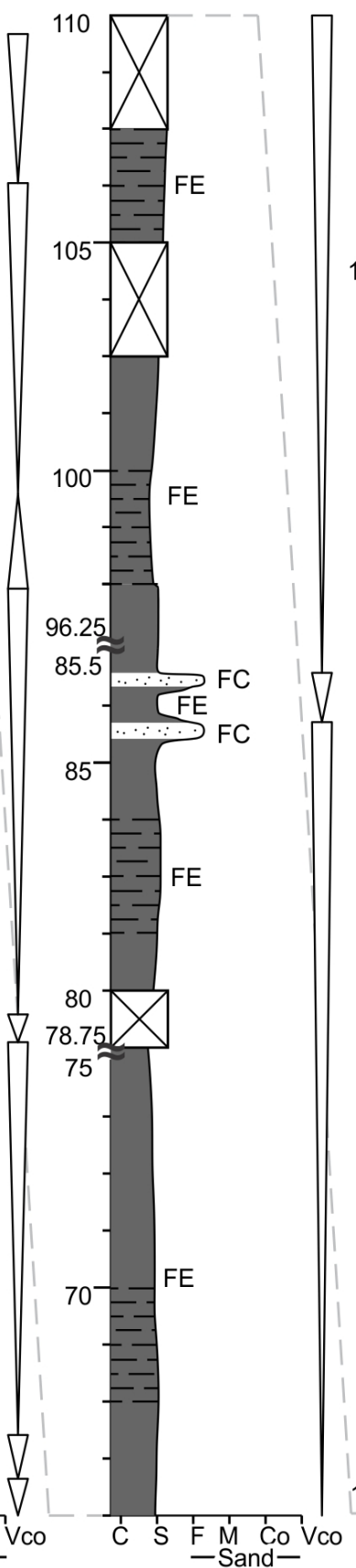

Metapelite (FE facies)

$\nabla$ Coarsening-upward sequence

$\triangle$ Fining-upward sequence
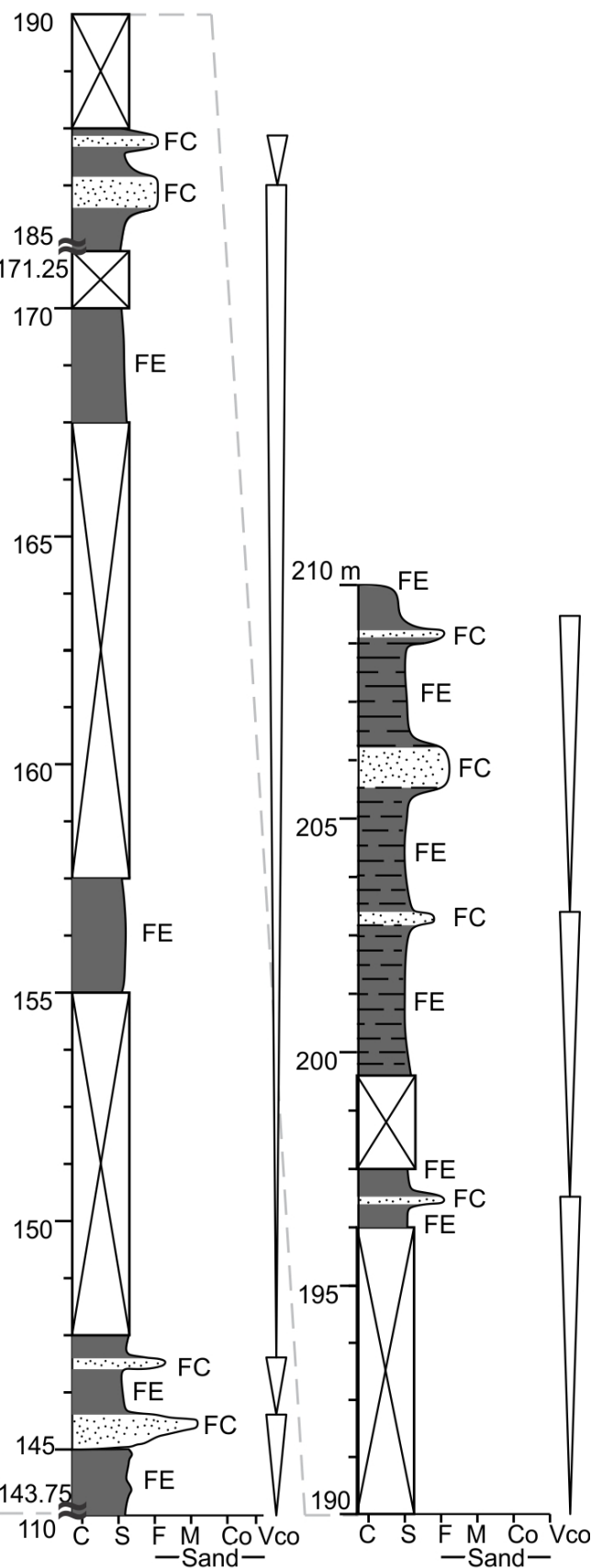

- - Planar bedding See Figure 10

Grain size: clay $(C)$, silt $(S)$, fine sand $(F)$, medium sand $(M)$, coarse sand $(C o)$ and very coarse sand $(C o)$

Figure 9. Stratigraphic section IV of Sabará Group in the inverse limb of Gandarela syncline. 
through or tabular cross-bedding and metaconglomerate lenses) and (ii) delta-fed turbidity sedimentation (intercalation of centimetric to decimetric fine-grained metasandstone and iron-rich metapelite without internal structures). The age distribution of GD-06 (Tab. 2, Fig. 13) shows a number of Neo- to Paleoarchean ages, with peaks at 2,786 $\pm 10 \mathrm{Ma}$ (weighted mean age of the
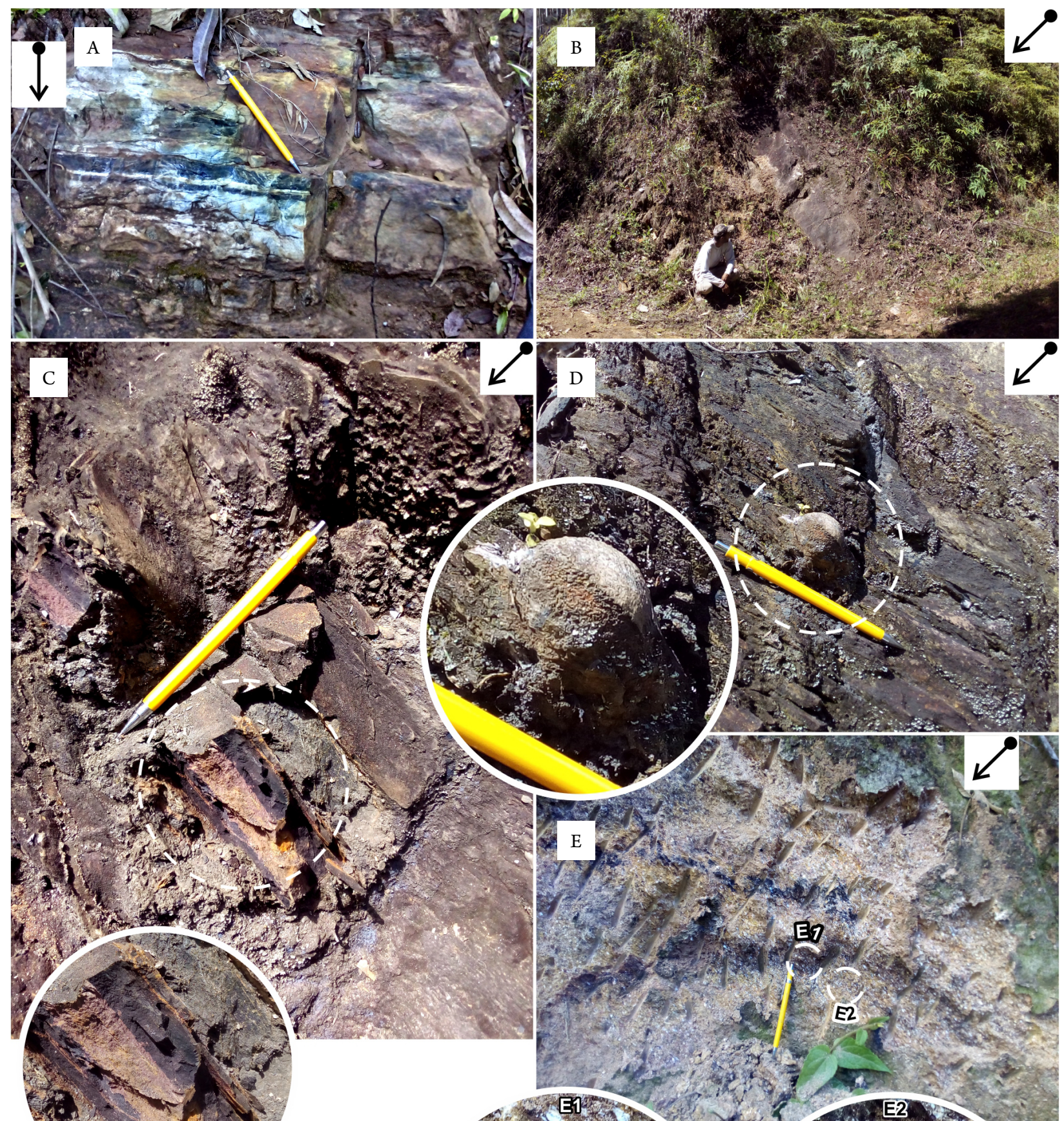

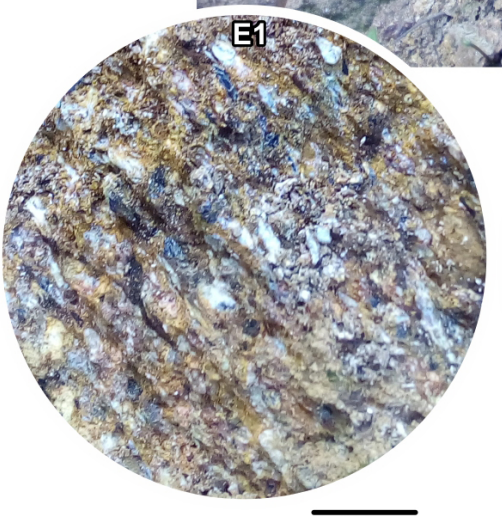

T25

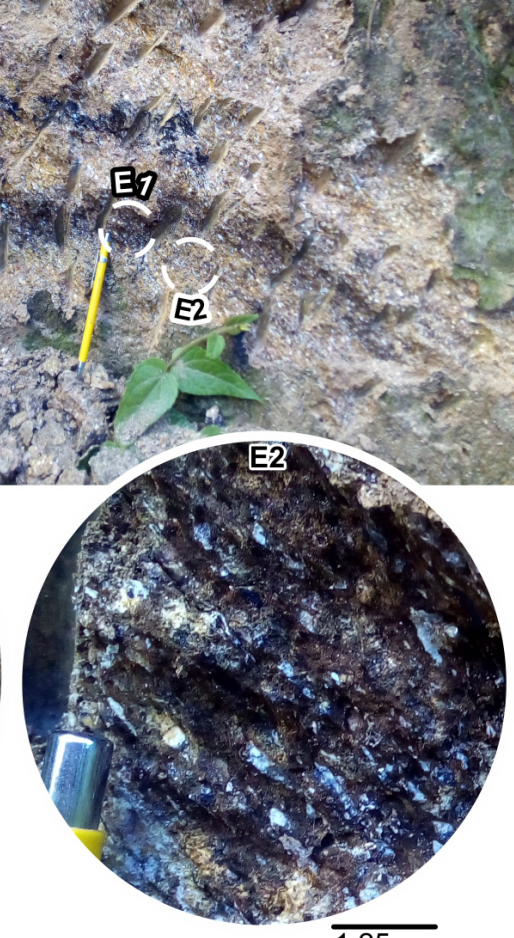

$\overline{1.25 \mathrm{~cm}}$

Figure 10. Photos from the stratigraphic section IV (Sabará Group in the inverse limb of Gandarela syncline). The photos are of a road section with a view from WSW, pencil: $15 \mathrm{~cm}$. (A) Medium-grained metasandstone (light bands) interlayered with metapelite (dark bands). Photo of road floor (view from S, 650136/7788896, pencil: $15 \mathrm{~cm}$ ). (B) and (C) Medium-grained metasandstone interlayered with metapelite. (D) Metapelite with a boulder $(\sim 3.7 \mathrm{~cm})$. (E) Metapelite milky and smoke quartz granules are highlighted $(\mathrm{E} 1$ and E2). 

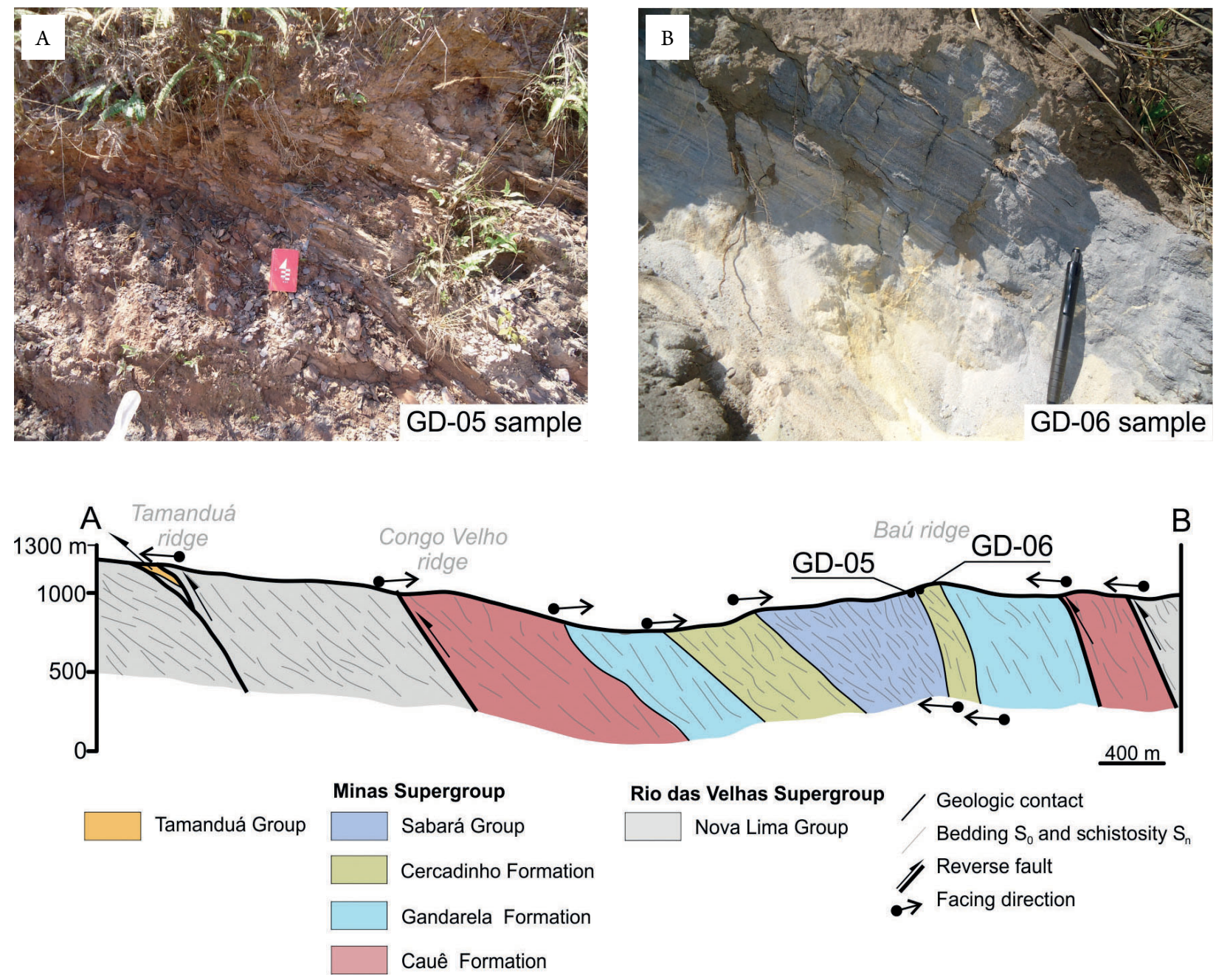

Figure 11. Metapelite of Sabará Group — sample GD-05 (A) — and metasandstone of Cercadinho Formation — sample GD-06 (B) in the Baú ridge, view from $\mathrm{E}$. The location is marked in geologic profile $\mathrm{AB}$.

\section{GD-05: Sabará Group}

\begin{tabular}{|c|c|c|c|c|}
\hline $\begin{array}{l}\mathbf{S}-\mathbf{0 2 6} \\
2130 \pm 20 \mathrm{Ma} \\
\text { Th/U: } 1.09\end{array}$ & (o) $\begin{array}{l}\mathbf{S - 0 3 2} \\
2159 \pm 19 \mathrm{Ma} \\
\mathrm{Th} / \mathrm{U}: 0.74\end{array}$ & $\begin{array}{l}\text { S-024 } \\
2122 \pm 20 \mathrm{Ma} \\
\text { Th/U: } 0.73\end{array}$ & $\begin{array}{l}\text { S-057 } \\
2780 \pm 18 \mathrm{Ma} \\
\text { Th/U: } 0.62\end{array}$ & $\begin{array}{l}\mathbf{S - 0 4 3} \\
2485 \pm 19 \mathrm{Ma} \\
\mathrm{Th} / \mathrm{U}: 0.70\end{array}$ \\
\hline $\begin{array}{l}\mathbf{S}-\mathbf{0 3 0} \\
2153 \pm 19 \mathrm{Ma} \\
\text { Th/U: } 1.13\end{array}$ & $\begin{array}{l}\text { S-023 } \\
2119 \pm 22 \mathrm{Ma} \\
\text { Th/U: } 0.69\end{array}$ & $\begin{array}{l}\text { S-008 } \\
2773 \pm 17 \mathrm{Ma} \\
\text { Th/U: } 0.95\end{array}$ & (0) $\begin{array}{l}\text { S-031 } \\
2155 \pm 21 \mathrm{Ma} \\
\text { Th/U: } 0.40\end{array}$ & \\
\hline $\begin{array}{l}\mathbf{S - 0 0 4} \\
1987 \pm 21 \mathrm{Ma} \\
\text { Th/U: } 0.68\end{array}$ & $\begin{array}{l}\text { S-028 } \\
2089 \pm 19 \mathrm{Ma} \\
\mathrm{Th} / \mathrm{U}: 0.71\end{array}$ & 8. $\begin{array}{l}\text { S-050 } \\
2711 \pm 19 \mathrm{Ma} \\
\text { Th/U: } 0.87\end{array}$ & $\begin{array}{l}\text { S-035 } \\
2182 \pm 21 \mathrm{Ma} \\
\text { Th/U: } 0.77\end{array}$ & \\
\hline
\end{tabular}

GD-06: Cercadinho Formation (Piracicaba Group)

1) C-058

$2916 \pm 17 \mathrm{Ma}$

$\mathrm{Th} / \mathrm{U}: 0.76$

C-120

$3160 \pm 23 \mathrm{Ma}$

Th/U: 1.36

C-044

$2894 \pm 18 \mathrm{Ma}$ Th/U: 0.74

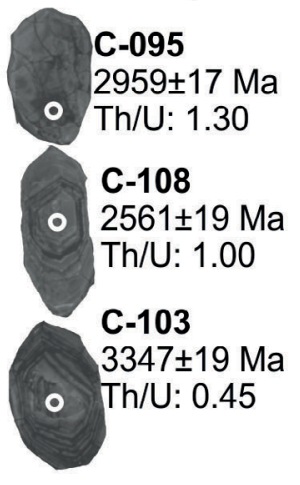

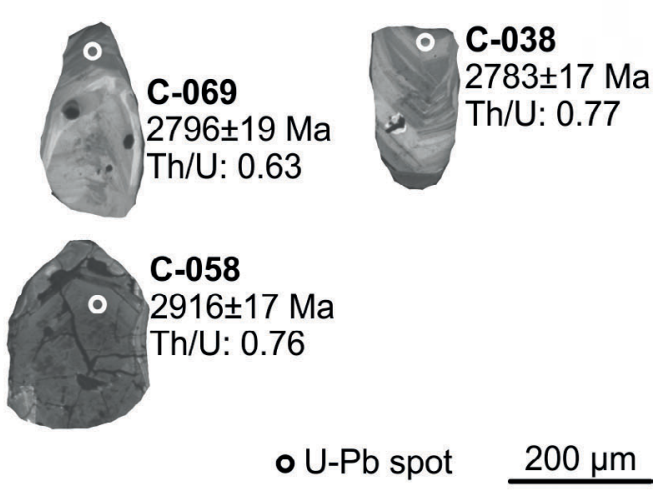

Figure 12. Cathodoluminescence image, ${ }^{207} \mathrm{~Pb} /{ }^{206} \mathrm{~Pb}$ age and $\mathrm{Th} / \mathrm{U}$ of some zircon grains from Cercadinho Formation (Piracicaba Group) and Sabará Group rocks. The spot numbers refer to the supplementary data in the online version of this article. 
youngest cluster, Fig. 13C), 3,034 Ma, 3,233 Ma and 3,347 Ma, confirming previous work (e.g., Machado et al. 1996, Mendes et al. 2014), which indicated the dominant Achaean terrain as source areas for this unit. No maximum sedimentation age can be inferred as younger than Gandarela Formation, dated by Babinski et al. (1995) at ca. $2420 \mathrm{Ma}$. The DA is proposed by Bekker et al. (2003) and Cabral \& Zeh (2015) (Tab. 2) at ca. 2180 Ma.
We propose that the Sabará Group represents a fine turbidite system. The sediments were transported at long distance from the coastline by a low-gradient fluvial system (Bouma 2000). From that point onwards, the sediments were transported by sliding and slumping across the self and slope, where it was accumulated (Bouma 2000). The Sabará Group is interpreted as syn-orogenic sedimentation through mass-transport process in
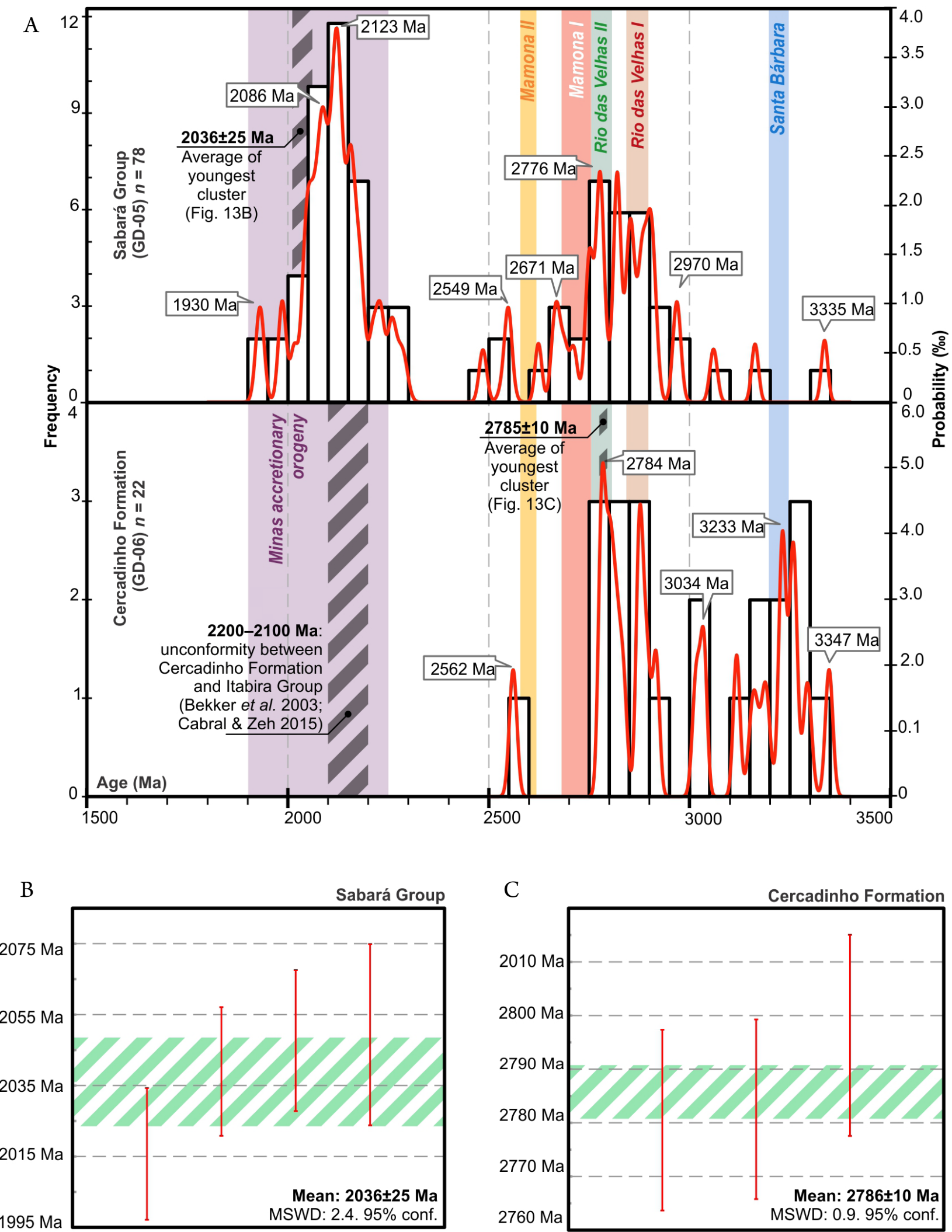

Figure 13. (A) Zircon age distribution of the Sabará Group and the Cercadinho Formation at the Gandarela syncline. Average of the youngest cluster of the Sabará Group (B) and the Cercadinho Formation (C) calculated by ${ }^{207} \mathrm{~Pb} /{ }^{206} \mathrm{~Pb}$ with two standard deviations $(2 \sigma)$. 
a compartmentalized foreland basin, in three sub-basin, development during Minas accretionary orogeny (Reis et al. 2002). The facies succession of Sabará Group in Gandarela syncline is like the stratigraphy framework of the northeast sub-basin of Reis et al. (2002). In this sub-basin, the fine-grained rocks are predominant over the metaconglomerate, metadiamictite and metagraywacke; they concluded this sedimentation was in the deep and/or distal environment. The immature coarse-grained rocks mainly shed the south sub-basin, which is close to the source area and collisional front. The intermediate sub-basin consists of coarse-grained rock, which is mostly formed by sediments derived from proximal terrains. The weighted mean age of GD-05 youngest cluster indicates 2,036 $\pm 25 \mathrm{Ma}$ as its maximum DA (Tab. 2, Fig. 13B). The main sedimentary provenance is the Rhyacian continental crust $(2,286-2,052 \mathrm{Ma})$ and can be linked to the Mantiqueira Province and Mineiro Belt in the eastern and southern margins of São Francisco Craton (Campos \& Carneiro 2008, Ávila et al. 2010, 2014, Seixas et al. 2012, Teixeira et al. 2015). The crustal reworking of the metavolcanossedimentary sequence of Rio das Velhas Supergroup and the granite-gneiss complexes of Quadrilátero Ferrifero constitute the second most frequent sedimentary sources. These populations represent the Archean events, Santa Bárbara, Rio das Velhas (I and II) and Mamona (I and II).

The tectonic setting of a sedimentary basin is reflected in the cumulative proportion of the detrital zircon ages for a given sample. It is related to the difference between the crystallization age (CA) of a zircon grain and the estimated DA of the unit that the sample belongs to (Cawood et al. 2012). The cumulative proportion of the detrital ages obtained from the sample GD-06, Cercadinho Formation (Piracicaba Group), reveals an extensional basin pattern (Fig. 14), since the CAs of the zircon grains are, at least, five hundred million years older than the depositional age. The GD-06 age distribution is similar to the data from the northwest (Mendes et al. 2014, Fig. 2) and southwest (Cassino 2014; Fig. 2) portions of the Quadrilátero Ferrífero. This denotes a similar tectonic setting during the deposition of the Cercadinho Formation throughout the Minas basin. The younger ages in GD-05 (Sabará Group) are in accordance with a convergent basin, whereas the data of Martínez-Dopico et al. (2017) defines a collisional basin as stated by Machado et al. (1996), which relates the sedimentation of the Sabará Group to igneous activities during the Minas accretionary orogeny. This is due to the great contribution of zircon grains with ages near the maximum depositional age of the Sabara Group. This may be a reflection of the reduced number of concordant data or sedimentation condition.

Cercadinho Formation rests directly on the Siderian chemical units of the Itabira Group and marks the resumption of the siliciclastic filling of the Minas basin, mainly derived from the granites generated during the Santa Bárbara and Rio das Velhas II tectonomagmatic events, and/or the crustal reworking of the installed basins during those events, as recorded in Rio das Velhas Supergroup and indicated in the histogram (Fig. 13). The younger age $(2,561 \mathrm{Ma})$ may be an indication of erosion of the Minas basin itself, as suggested by the proximity to the depositional age of Moeda Formation (Martínez-Dopico et al. 2017). Aging of the sources can be attributed to exhumation and erosion of the Archean crust in response to a tectonic rearrangement in the region and/or to the continuous process of peneplanation of the Siderian or more recent terrains. In regional terms, the Sabará Group is marked by an extensive pelitic sedimentation in the northeast Quadrilátero Ferrífero, whose main population obtained in this work, 2,300-1,932 Ma, may indicate the strong influence of the Minas basin inversion during the Orosirian-Rhyacian period. The Minas accretionary orogeny possibly exhumed the Siderian units and the granitic rocks that occur in the south and east of Quadrilátero Ferrifero, generating large and distant source areas that would explain the predominantly fine sedimentation of the Sabará Group. Zircons populations of ca. 3,138 Ma are consistent with Santa Bárbara granite genesis, but the $>3,300 \mathrm{Ma}$ zircon

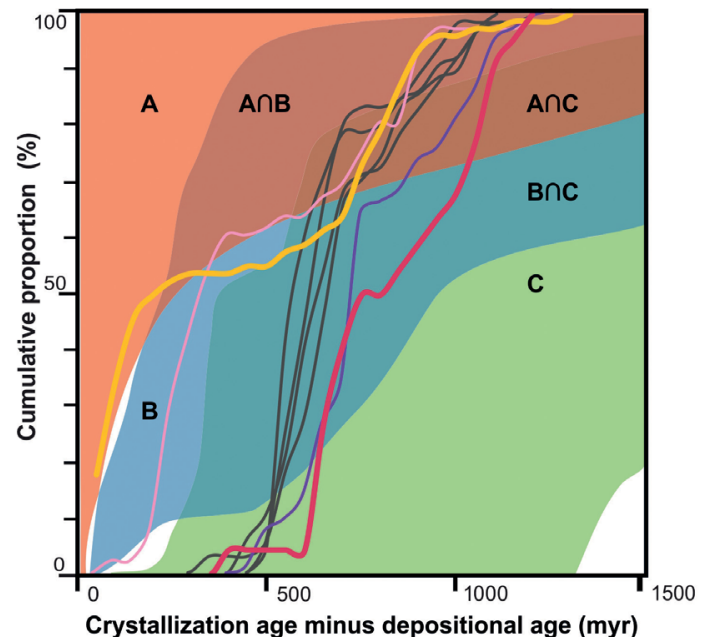

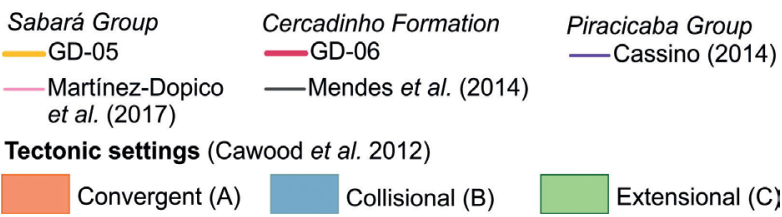

Figure 14. Cumulative distribution of detrital zircon ages of Cercadinho Formation and Sabará Group assuming depositional ages of 2,180 and 2,036 Ma, respectively, and a schematic tectonic section of the different tectonic arrangements (based on Cawood et al. 2012). The diagram is limited to $1,500 \mathrm{myr}$, since the data are concentrated up to 1,300 myr in the abscissa axis.

Table 2. Statistical analysis of age populations of detrital zircons in the Gandarela syncline from this paper.

\begin{tabular}{|c|c|c|c|c|c|}
\hline \multirow{2}{*}{ Unit } & \multirow{2}{*}{ Samples } & \multirow{2}{*}{$\begin{array}{l}\text { Youngest single grain } \\
\text { (concordance) }\end{array}$} & \multicolumn{2}{|c|}{ Youngest grain cluster with $n \geq 3$} & \multirow{2}{*}{ Deposition age } \\
\hline & & & Peak age probability & Weighted mean age & \\
\hline Sabará Group & GD-05 & $\begin{array}{c}1,929 \pm 21 \mathrm{Ma} \\
(98.6 \%)\end{array}$ & $2,043 \mathrm{Ma}$ & $2,036 \pm 25 \mathrm{Ma}$ & $\begin{array}{l}2,036 \pm 25 \mathrm{Ma} \\
\text { (maximum) }\end{array}$ \\
\hline Cercadinho Formation & GD-06 & $\begin{array}{l}2,561 \pm 19 \mathrm{Ma} \\
(100.1 \%)\end{array}$ & $2,784 \mathrm{Ma}$ & $2,785 \pm 10 \mathrm{Ma}$ & $\begin{array}{l}\text { ca. } 2,180 \mathrm{Ma}^{1} \\
(\text { minimum })\end{array}$ \\
\hline
\end{tabular}

${ }^{1}$ Proposed age by Cabral \& Zeh (2015). 
suggests a Paleoarchean crust segment, which was not determined in the São Francisco craton, as previously recognized by Moreira et al. (2016).

\section{CONCLUSIONS}

This study establishes new evidence of the evolution of upper units of Minas basin in the northeastern Quadrilátero Ferrífero. The sedimentologic and geochronological data indicate that after the rift phase (Moeda Formation) and passive margin (Batatal Formation and Itabira Group), the Minas basin grades into a convergent setting in response of Minas accretionary orogeny.

The sediments that compose the rocks of Cercadinho Formation were deposited in marine environments and extensional setting (Fig. 14). The Cercadinho sedimentation was mainly fed by a fluvio-deltaic system able to produce gravity flow that deposited massive sandy bodies in the northeast part of Quadrilátero Ferrífero before ca. 2,180 Ma (Bekker et al.2003, Cabral \& Zeh 2015). These sediments were mainly derived from the crustal reworking of Rio das Velhas greenstone belt and granite-gneiss complexes.

The large percentage of Rhyacian zircon age suggests that the sediments of Sabará Group rocks were derived from terrains exhumed during the Minas accretionary orogeny. This event drastically changes the sediment transport competence and source areas with the deposition of pelitic and sandy bodies after 2,030 Ma in a collisional basin. The main source was probably located to the eastern and southern border of the São Francisco craton, Mantiqueira and Mineiro Belt terrains, respectively.

\section{ACKNOWLEDGMENTS}

This project was sponsored by FAPEMIG - Brazil (CRA APEQ 03793-16), Fapemig-Vale (CRA RDP-0067-10). We thank the Microanalysis Laboratory of the Universidade Federal de Ouro Preto, a member of the Microscopy and Microanalysis Network of Minas Gerais State/Brazil/ FAPEMIG, for the CL images. We are grateful for the comments and guidance from the editor-in-chief Claudio Riccomini, associate editor Umberto Cordani, three anonymous reviewers and Carita Augustsson that helped to significantly improve this paper. We also thank Coordenação de Aperfeiçoamento de Pessoal de Nível Superior - Brasil (CAPES) for their partial financial assistance and support on research (Finance Code 001).

\section{ARTICLE INFORMATION}

Manuscript ID: 20180095. Received on: 08/31/2018. Approved on: 02/04/2019.

L.F.D. wrote the first version, corrected the article, and prepared all the images and tables. M.M. aided in the article revision and provided suggestions for the abstract, introduction and faciological description. C.L. made suggestions on the methodology for geochronology and assisted in data interpretation.

Competing interests: The authors declare no competing interests.

\section{REFERENCES}

Aguilar C., Alkmim F.F., Lana C., Farina F. 2017. Palaeoproterozoic assembly of the São Francisco craton, SE Brazil: New insights from U-Pb titanite and monazite dating. Precambrian Research, 289:95-115. https:// doi.org/10.1016/j.precamres.2016.12.001

Albert C., Farina F., Lana C., Stevens G., Storey C., Gerdes A., MartínezDopico C.I. 2016. Archean crustal evolution in the Southern São Francisco craton, Brazil: Constraints from U-Pb, Lu-Hf and $\mathrm{O}$ isotope analyses. Lithos, 266-267:64-86. https://doi.org/10.1016/j.lithos.2016.09.029

Alkmim F.F. 1987. Modelo Deposicional para a sequência de metassedimentos da Serra de Ouro Branco, Quadrilátero Ferrífero, Minas Gerais. Boletim da Sociedade Brasileira de Geologia Núcleo MG, 6:47-68.

Alkmim F.F. \& Marshak S. 1998. Transamazonian Orogeny in the Southern São Francisco Craton Region, Minas Gerais, Brazil: evidence for Paleoproterozoic collision and collapse in the Quadrilátero Ferrífero. Precambrian Research, 90(1-2):29-58. https://doi.org/10.1016/ S0301-9268(98)00032-1

Alkmim F.F., Lana C. de C., Duque T.R.F. 2014. Zircões detríticos do Grupo Itacolomi e o registro do soerguimento do Cinturão Mineiro. In: Congresso Brasileiro de Geologia, 47., Salvador. Anais, p. 1802.

Alkmim F.F. \& Martins-Neto M.A. 2012. Proterozoic first-order sedimentary sequences of the São Francisco craton, eastern Brazil. Marine and Petroleum Geology, 33(1):127-139. https://doi.org/10.1016/j. marpetgeo.2011.08.011
Almeida D.E. 1977. O Cráton do São Francisco. Revista Brasileira de Geociências, 7:349-364.

Almeida F.F.M., Hasui Y., Brito Neves B.B., Fuck R.A. 1981. Brazilian structural provinces: An introduction. Earth-Science Reviews, 17(1-2):1-29. https://doi.org/10.1016/0012-8252(81)90003-9

Andersen T. 2005. Detrital zircons as tracers of sedimentary provenance: Limiting conditions from statistics and numerical simulation. Chemical Geology, 216(3-4):249-270. https://doi.org/10.1016/j. chemgeo.2004.11.013

Ávila C.A., Teixeira W., Bongiolo E.M., Dussin I.A., Vieira T.A.T. 2014. Rhyacian evolution of subvolcanic and metasedimentary rocks of the southern segment of the Mineiro belt, São Francisco Craton, Brazil. Precambrian Research, 243, 221-251. https://doi.org/10.1016/j. precamres.2013.12.028

Ávila C.A., Teixeira W., Cordani U.G., Moura C.A.V., Pereira R.M. 2010. Rhyacian (2.23-2.20Ga) juvenile accretion in the southern São Francisco craton, Brazil: Geochemical and isotopic evidence from the Serrinha magmatic suite, Mineiro belt. Journal of South American Earth Sciences, 29(2):464-482. https://doi.org/10.1016/j.jsames.2009.07.009

Babinski M., Chemale Jr. F., Van Schmus W.R. 1995. The Pb/ $\mathrm{Pb}$ age of the Minas Supergroup carbonate rocks, Quadrilátero Ferrífero, Brazil. Precambrian Research, 72(3-4):235-245. https://doi. org/10.1016/0301-9268(94)00091-5 
Barbosa J.S.F. \& Sabaté P. 2004. Archean and Paleoproterozoic crust of the São Francisco Craton, Bahia, Brazil: Geodynamic features. Precambrian Research, 133(1-2):1-27. https://doi.org/10.1016/j. precamres.2004.03.001

Bass J.H. 2004. Conditions for formation of massive turbiditic sandstones by primary depositional processes. Sedimentary Geology, 166(3-4):293-310. https://doi.org/10.1016/j.sedgeo.2004.01.011

Bekker A., Sial A.N., Karhu J.A., Ferreira V.P., Noce C.M., Kaufman A.J., Romano A.W., Pimentel M.M. 2003. Chemostratigraphy of carbonates from the Minas Supergroup, quadrilátero ferrífero (iron quadrangle), Brazil: A stratigraphic record of early proterozoic atmospheric, biogeochemical and climatic change. American Journal of Science, 303(10):865-904. https://doi. org/10.2475/ajs.303.10.865

Bouma A.H. 2000. Fine-grained, mud-rich turbidite systems: model and comparison with coarsegrained, sand-rich systems. In: Bouma A.H. \& Stone C.G. (eds.), Fine-grained turbidite systems. AAPG Memoir 72/SEPM Special Publication, 68, p. 9-20.

Brandalise L.A. \& Heineck C.A. (eds.). 1999. Programa Levantamentos Geológicos Básicos do Brasil. Belo Horizonte, Folha SE.23-Z-C-IV, Estado de Minas Gerais. Escala 1:100.000. Brasilia, CPRM - Serviço Geológico do Brasil, 104 p.

Brito-Neves B.B. de 2011. The Paleoproterozoic in the South-American continent: Diversity in the geologic time. Journal of South American Earth Sciences, 32(4):270-286. https://doi.org/10.1016/j.jsames.2011.02.004

Brueckner H.K., Cunningham D., Alkmim F.F., Marshak S. 2000. Tectonic implications of Precambrian Sm-Nd dates from the southern Sao Francisco craton and adjacent Aracuai and Ribeira belts, Brazil. Precambrian Research, 99(3-4):255-269. https://doi.org/10.1016/S0301-9268(99)00065-0

Cabral A.R. \& Zeh A. 2015. Celebrating the Centenary of "The Geology of Central Minas Gerais, Brazil": An Insight from the Sítio Largo Amphibolite. Journal of Geology, 123(4):337-354. https://doi.org/10.1086/682047

Cabral A.R., Zeh A., Koglin N., Seabra Gomes Jr. A.A., Viana D.J., Lehmann B. 2012. Dating the Itabira iron formation, Quadrilátero Ferrífero of Minas Gerais, Brazil, at 2.65Ga: Depositional U-Pb age of zircon from a metavolcanic layer. Precambrian Research, 204-205:40-45. https://doi. org/10.1016/j.precamres.2012.02.006

Campos J.C.S. \& Carneiro M.A. 2008. Neoarchean and Paleoproterozoic granitoids marginal to the Jeceaba-Bom Sucesso lineament (SE border of the southern São Francisco craton): Genesis and tectonic evolution. Journal of South American Earth Sciences. 26(4):463-484. https://doi.org/10.1016/j. jsames.2008.09.002

Cassino L.F. 2014. Distribuição de idades de zircões detríticos dos supergrupos Rio das Velhas e Minas na Serra de Ouro Preto, Quadrilátero Ferrifero, MG implicações para a evolução sedimentar e tectônica. Monography, Universidade Federal de Ouro Preto, Ouro Preto, 53 p.

Cawood P.A., Hawkesworth C.J., Dhuime B. 2012. Detrital zircon record and tectonic setting. Geology, 40(10):875-878. https://doi.org/10.1130/ G32945.1

Chemale Jr. F., Rosière C.A., Endo I. 1994. The tectonic evolution of the Quadrilátero Ferrífero, Minas Gerais, Brazil. Precambrian Research, 65(14):25-54. https://doi.org/10.1016/0301-9268(94)90098-1

Coe A.L. 2010. Geological field techniques. London, Wiley-Blackwell, 323 p.

Companhia de Pesquisa de Recursos Minerais - Serviço Geológico do Brasil (CPRM). Geobank. Available at: <http://geobank.cprm.gov.br/>. Acessed on: Jan. 30, 2018.

Crocco-Rodrigues F.A. 1991. Sistemas de Cavalgamento e Geologia Estrutural da Serra das Cambotas, Quadrilátero Ferrifero (MG). Dissertation. Universidade de Brasília, Brasília, 163 p.

Dias S.P. 2019. Contribuição ao estudo sedimentar do Grupo Tamanduá, Supergrupo Espinhaço, na serra das Cambotas, região de Barão de Cocais, Minas Gerais. Thesis, Universidade Federal de Ouro Preto, Ouro Preto.

Dickinson W.R. \& Gehrels G.E. 2009. Use of U-Pb ages of detrital zircons to infer maximum depositional ages of strata: A test against a Colorado Plateau Mesozoic database. Earth and Planetary Science Letters, 288(1-2):115-125. https://doi.org/10.1016/j.epsl.2009.09.013

Dorr II J.V.N. 1969. Physiographic, stratigraphic, and structural development of the Quadrilatero Ferrifero, Minas Gerais, Brazil. U.S. Geology Survey Professional Paper, 641-A:1-110. https://doi.org/10.3133/pp641A
Dutra L.F. 2017. Caracterização geocronológica U-Th-Pb de zircões detríticos na porção nordeste do sinclinal Gandarela - implicações para evolução sedimentar e geotectônica do Quadrilátero Ferrífero. Dissertation, Universidade Federal de Ouro Preto, Ouro Preto, 100 p.

Endo I. \& Fonseca M.A. 1992. Sistema de cisalhamento Fundão-Cambotas no Quadrilátero Ferrífero, geometria e cinemática. Revista Escola de Minas, 45(1-2):15-17

Endo I. \& Machado R. 2002. Reavaliação e Novos Dados Geocronológicos $(\mathrm{Pb} / \mathrm{Pb}$ e K/Ar) da Região do Quadrilátero Ferrífero e Adjacências. Geologia USP Série Cientifíca, 2:23-40. https://doi.org/10.5327/ S1519-874X2002000100005

Farina F., Albert C., Martínez-Dopico C.I., Aguilar Gil C., Moreira H.S., Hippertt J.P., Cutts K., Alkmim F.F., Lana C. 2016. The ArcheanPaleoproterozoic evolution of the Quadrilátero Ferrífero (Brasil): Current models and open questions. Journal of South American Earth Sciences, 68:421. https://doi.org/10.1016/j.jsames.2015.10.015

Fonseca M.A., Martins M.S., Dutra L.F., Faria I.C.G. 2018. Geometria do sinclinal Gandarela: implicações para a tectônica paleoproterozoica do Quadrilátero Ferrífero. In: Congresso Brasileiro de Geologia, 49. Proceedings... SBG, p. 912.

Gehrels G. 2014. Detrital Zircon U-Pb Geochronology Applied to Tectonics. Annual Review of Earth and Planetary Science, 42:127-149. https://doi.org/10.1146/annurev-earth-050212-124012

Gomes A.C.B. 2017. Arcabouço estratigráfico e estrutural do Grupo Tamanduá na serra das Cambotas, municípios de Barão de Cocais e Caeté, MG. Monograph, Universidade Federal de Ouro Preto, Ouro Preto, $55 \mathrm{p}$

Guadagnin F. \& Chemale Jr. F. 2015. Detrital zircon record of the Paleoproterozoic to Mesoproterozoic cratonic basins in the São Francisco Craton. Journal of South American Earth Sciences, 60:104-116. https://doi. org/10.1016/j.jsames.2015.02.007

Guimarães S.N.P., Ravat D., Hamza V.M. 2014. Combined use of the centroid and matched filtering spectral magnetic methods in determining thermomagnetic characteristics of the crust in the structural provinces of Central Brazil. Tectonophysics, 624-625:87-99. https://doi.org/10.1016/j. tecto.2014.01.025

Hartmann A., Endo I., Tadeu M., Suita F., Santos J.O.S., Frantz J.C., Carneiro M.A., McNaughton N.J., Barley M.E. 2006. Provenance and age delimitation of Quadrilátero Ferrífero sandstones based on zircon U-Pb isotopes. Journal of South American Earth Sciences, 20(4):273-285. https:// doi.org/10.1016/j.jsames.2005.07.015

Haughton P.D.W, Davis C., McCaffrey W., Barker S.P. 2009. Hybrid sediment gravity flow deposits - Classification, origin and significance. Marine and Petroleum Geology, 26(10):1900-1918. https://doi.org/10.1016/j. marpetgeo.2009.02.012

Hurley P.M., Rand J.R., Pinson Jr. W.H., Fairbairn H.W., de Almeida F.F.M., Melcher G.C., Cordani U.G., Kawashita K., Vandoros P. 1967. Test of Continental Drift by Comparison of Radiometric Ages. Science, 157(3788):495-500. https://doi.org/10.1126/science.157.3788.495

Jackson S.E., Pearson N.J., Griffin W.L., Belousova E.A. 2004. The application of laser ablation-inductively coupled plasma-mass spectrometry to in situ U-Pb zircon geochronology. Chemical Geology, 211(1-2):47-69. https://doi.org/10.1016/j.chemgeo.2004.06.017

Katahira D.F. 2013. Mapeamento geológico em escala 1:25.000, na junção entre o Sinclinal do Gandarela e a Serra dos Cambotas, de Barão de Cocais - MG. Monography, Universidade Federal de Minas Gerais, Belo Horizonte, 111 p.

Koglin N., Zeh A., Cabral A.R., Gomes Jr. A.A.S., Corrêa Neto A.V. Brunetto W.J., Galbiatti H. 2014. Depositional age and sediment source of the auriferous Moeda Formation, Quadrilátero Ferrífero of Minas Gerais, Brazil: New constraints from $\mathrm{U}-\mathrm{Pb}-\mathrm{Hf}$ isotopes in zircon and xenotime. Precambrian Research, 255(Part 1):96-108. https://doi.org/10.1016/j. precamres.2014.09.010

Lana C., Alkmim F.F., Armstrong R., Scholz R., Romano R., Nalini Jr. H.A. 2013. The ancestry and magmatic evolution of Archaean TTG rocks of the Quadrilátero Ferrífero province, southeast Brazil. Precambrian Research, 231:157-173. https://doi.org/10.1016/j.precamres.2013.03.008

Lobato L.M., Baltazar O.F., Reis L.B., Achtschin A.B., Baars F.J., Timbó M.A., Berni G.V., Mendonça B.R.V., Ferreira D. 2005. Projeto Geologia do Quadrilátero Ferrífero - Integração e Correção Cartográfica em SIG com Nota Explicativa. Belo Horizonte, $68 \mathrm{p}$ 
Lowe D.R. 1982. Sediment gravity flows: II Depositional models with special reference to the deposits of high-density turbidity currents. Journal of Sedimentary Research, 52:279-297. https://doi. org/10.1306/212F7F31-2B24-11D7-8648000102C1865D

Ludwig K.R. 2009. User's Manual for Isoplot 3.70. Berkeley, Berkeley Geochronology Center Special Publication No. 4, 76 p.

Machado N. \& Carneiro M. 1992. U-Pb evidence of late Archean tectonothermal activity in the southern São Francisco shield, Brazil. Canadian Journal of Earth Sciences, 29(11):2341-2346. https://doi.org/10.1139/e92-182

Machado N., Noce C.M., Ladeira E.A., Belo de Oliveira O. 1992. U-Pb Geochronology of Archean magmatism and Proterozoic metamorphism in the Quadrilátero Ferrífero, southern São Francisco craton, Brazil. Geological Society of America Bulletin, 104(9):1221-1227. https://doi. org/10.1130/0016-7606(1992)104\%3C1221:UPGOAM\%3E2.3.CO;2

Machado N., Schrank A., Noce C.M., Gauthier G. 1996. Ages of detrital zircon from Archean-Paleoproterozoic sequences: Implications for Greenstone Belt setting and evolution of a Transamazonian foreland basin in Quadrilátero Ferrífero, southeast Brazil. Earth and Planetary Science Letters, 141(1-4):259-276. https://doi.org/10.1016/0012-821X(96)00054-4

Marshak S. \& Alkmim F.F. 1989. Proterozoic contraction/extension tectonics of the southern São Francisco Region, Minas Gerais, Brazil. Tectonics, 8(3):555-571. https://doi.org/10.1029/TC008i003p00555

Martínez-Dopico C.I., Lana C., Moreira H.S., Cassino L.F., Alkmim F.F. 2017. U-Pb ages and Hf-isotope data of detrital zircons from the late Neoarchean-Paleoproterozoic Minas Basin, SE Brazil. Precambrian Research, 291:143-161. https://doi.org/10.1016/j.precamres.2017.01.026

Mattern F. 2005. Ancient sand-rich submarine fans: depositional systems, models, identification, and analysis. Earth-Science Review, 70(3-4):167-202. https://doi.org/10.1016/j.earscirev.2004.12.001

Mendes M.D.C.O., Lobato L.M., Suckau V., Lana C. 2014. In situ LAICPMS U-Pb dating of detrital zircons from the Cercadinho Formation, Minas Supergroup. Geologia USP Série Científica, 14(1):55-68. https://doi. org/10.5327/Z1519-874X201400010004

Moore S.L. 1969. Geology and Ore Deposits of the Antônio dos Santos, Congo Sôco and Conceição do Rio Acima Quadrangles, Minas Gerais, Brazil. U.S. Geological Survey Professional Paper, 341-I: 1-50.

Moraes M.A.S. 1985. Reconhecimento de fácies sedimentares em rochas metamórficas da região de Ouro Preto, Minas Gerais. In: Simpósio de Geologia de Minas Gerais, 3. Boletim... SBG, v. 5, p. 84-93.

Moreira H.S., Lana C., Nalini Jr. H.A. 2016. The detrital zircon record of an Archaean convergent basin in the Southern São Francisco Craton, Brazil. Precambrian Research, 275:84-99. https://doi.org/10.1016/j. precamres.2015.12.015

MulderT, SyvitskiJ, Migeon S, Faugères J.C, Savoye B. 2003. Marine hyperpycnal flows: Initiation, behavior and related deposits. A review. Marine and Petroleum Geology, 20(6-8):861-882. https://doi.org/10.1016/j.marpetgeo.2003.01.003

Mutti E. 1992. Turbidite sandstones. Parma, Agip, Instituto di Geologia, Università di Parma, 275 p.

Mutti E., Tinterri R., Benevelli G., di Biase D., Cavanna G. 2003. Deltaic, mixed and turbidite sedimentation of ancient foreland basins. Marine and Petroleum Geology, 20(6-8):733-755. https://doi.org/10.1016/j.marpetgeo.2003.09.001

Mutti E., Tinterri R., Remacha E., Mavilla N., Angella S., Fava, L. 1999. An Introduction to the Analysis of Ancient Turbidite Basins from an Outcrop Perspective. AAPG Course Notes, 39, 93 p.

Neri M.E.N.V., Rosière C.A., De Carvalho Lana C. 2013. Supergrupo Minas na Serra de Bom Sucesso, extremo sudoeste do Quadrilátero Ferrífero - MG: Petrografia, geoquímica e isótopos de U-Pb. Geologia USP Série Científica, 13(2):175-202. https://doi.org/10.5327/Z1519-874X2013000200010

Noce C.M., Tassinari C., Lobato L.M. 2007. Geochronological framework of the Quadrilátero Ferrífero, with emphasis on the age of gold mineralization hosted in Archean greenstone belts. Ore Geology Reviews, 32(3-4):500-510. https://doi.org/10.1016/j.oregeorev.2005.03.019

Noce C.M., Zuccheti M., Baltazar O.F., Armstrong R., Dantas E., Renger F.E., Lobato L.M. 2005. Age of felsic volcanism and the role of ancient continental crust in the evolution of the Neoarchean Rio das Velhas greenstone belt (Quadrilátero Ferrífero, Brazil): U-Pb zircon dating of volcaniclastic graywackes. Precambrian Research, 141(1-2):67-82. https:// doi.org/10.1016/j.precamres.2005.08.002
Nunes F.S. 2016. Contribuição à estratigrafia e geocronologia U-Pb de zircões detríticos da Formação Moeda (Grupo Caraça, Supergrupo Minas) na Serra do Caraça, Quadrilátero Ferrífero, Minas Gerais. Thesis, Universidade Federal de Ouro Preto, Ouro Preto, $77 \mathrm{p}$.

Pullen A., Ibáñez-Mejía M., Gehrels G.E., Ibáñez-Mejía J.C., Pecha M. 2014. What happens when $\mathrm{n}=1000$ ? Creating large-n geochronological datasets with LA-ICP-MS for geologic investigations. Journal of Analytical Atomic Spectrometry, 29(6):971-980. https://doi.org/10.1039/c4ja00024b

Reeves R.G. 1966. Geology and mineral resources of the Monlevade and Rio Piracicaba quadrangles, Minas Gerais, Brazil. U.S. Geology Survey Professional Paper, 341-E:1-58.

Reis L.A., Martins-Neto M.A., Gomes N.S., Endo I., Jordt-Evangelista H. 2002. A bacia de antepaís paleoproterozoica Sabará, Quadrilátero Ferrífero. Revista Brasileira de Geociências, 32(1):27-42.

Renger F., Noce C.M., Romano A.W., Machado N. 1995. Evolução sedimentar do Supergrupo Minas: $500 \mathrm{Ma}$ de registro geológico no Quadrilátero Ferrífero, Minas Gerais, Brasil. Geonomos, 2:1-11. https://doi. org/10.18285/geonomos.v2i1.227

Romano R., Lana C., Alkmim F.F., Stevens G., Armstrong R. 2013. Stabilization of the southern portion of the São Francisco craton, SE Brazil, through a long-lived period of potassic magmatism. Precambrian Research, 224:143-159. https://doi.org/10.1016/j.precamres.2012.09.002

Rosière C.A. \& Chemale Jr. F. 2000. Brazilian iron formations and their geological setting. Revista Brasileira de Geociências, 30(2):274-278.

Sanglard J.C.D., Rosière C.A., Santos J.O.S., McNaughton N.J., Fletcher I.R. 2014. A estrutura do segmento oeste da Serra do Curral, Quadrilátero Ferrífero, e o controle tectônico das acumulações compactas de alto teor em Fe. Geologia USP Série Científica, 14(1):81-95. https://doi.org/10.5327/ Z1519-874X201400010006

Santos M.M., Lana C., Scholz R., Buick I., Schmitz M.D., Kamo S.L., Gerdes A., Corfu F., Tapster S., Lancaster P., Storey C.D., Basei M.A.S., Tohver E., Alkmim A.R., Nalini H., Krambrock K., Fantini C., Wiedenbeck M. 2017. A New Appraisal of Sri Lankan BB Zircon as a Reference Material for LAICP-MS U-Pb Geochronology and Lu-Hf Isotope Tracing. Geostandards and Geoanalytical Research, 41(3):335-358. https://doi.org/10.1111/ ggr.12167

Saraiva M.V.O. 2012. Mapeamento Geológico em Escala 1 : 10.000 na Região a oeste de Barão de Cocais - MG. Monography, Universidade Federal de Minas Gerais, Belo Horizonte, $110 \mathrm{p}$.

Seixas L.A.R., David J., Stevenson R. 2012. Geochemistry, Nd isotopes and $\mathrm{U}-\mathrm{Pb}$ geochronology of a 2350Ma TTG suite, Minas Gerais, Brazil: Implications for the crustal evolution of the southern São Francisco craton. Precambrian Research, 196-197:61-80. https://doi.org/10.1016/j. precamres.2011.11.002

Shanmugam G. 2016. Sumbarine fans: A critial retrospective (1950-2015). Journal of Palaeogeography, 5(2):110-184. https://doi.org/10.1016/j. jop.2015.08.011

Sial A.N., Dardenne M.A., Misi A., Pedreira A.J., Gaucher C., Ferreira V.P., Silva Filho M.A., Uhlein A., Soares A.C.P., Santos R.V., Silva M.E., Babinski M., Alvarenga C.J.S., Fairchild T.R., Pimentel M.M. 2009. The São Francisco Palaeocontinent. Developments in Precambrian Geology, 16:31-69. https:// doi.org/10.1016/S0166-2635(09)01603-X

Silva A.M., Chemale Jr F., Kumuyumjian R.M., Heaman L. 1995. Mafic dike swarms of Quadrilátero Ferrífero and Southern Espinhaço, Minas Gerais, Brazil. Revista Brasileira de Geociências, 25:124-137.

Simmons G.C. 1968. Geology and Mineral Resources of the Barão de Cocais Area, Minas Gerais, Brazil. U.S. Geology Survey Professional Paper, 341-H:1-46.

Souza P.C. \& Müller G. 1984. Primeiras estruturas algais comprovadas na Formação Gandarela, Quadrilátero Ferrífero. Revista Escola de Minas, 37(2):161-198.

Spencer C.J., Kirkland C.L., Taylor R.J.M. 2016. Strategies towards statistically robust interpretations of in situ U-Pb zircon geochronology. Geoscience Frontiers, 7(4):581-589. https://doi.org/10.1016/j. gsf.2015.11.006

Stacey J.S. \& Kramers J.D. 1975. Approximation of terrestrial lead isotope evolution by a two-stage model. Earth and Planetary Science Letters, 26(2):207-221. https://doi.org/10.1016/0012-821X(75)90088-6 
Braz. J. Geol. (2019), 49(2): e20180095

Stow D.A.V. \& Johansson M. 2000. Deep-water massive sands: nature, origin and hydrocarbon implications. Marine and Petroleum Geology, 17(2):145174. http://dx.doi.org/10.1016/S0264-8172(99)00051-3

Teixeira W., Ávila C.A., Dussin I.A., Corrêa Neto A.V., Bongiolo E.M., Santos J.O., Barbosa N.S. 2015. A juvenile accretion episode (2.35-2.32Ga) in the Mineiro belt and its role to the Minas accretionary orogeny: Zircon U-Pb-Hf and geochemical evidences. Precambrian Research, 256:148-169. https://doi.org/10.1016/j.precamres.2014.11.009

Teixeira W. \& Figueiredo M.C.H. 1991. An outline of Early Proterozoic crustal evolution in the São Francisco craton, Brazil: a review. Precambrian Research, 53(1-2):1-22. https://doi.org/10.1016/0301-9268(91)90003-S

Teixeira W., Oliveira E.P., Marques L.S. 2017. Nature and Evolution of the Archean Crust of the São Francisco Craton. In: Heilbron M., Cordani U.G., Alkmim F.F. (eds.), São Francisco Craton, Eastern Brazil: Tectonic Genealogy of a Miniature Continent. New York, Springer International Publishing, p. 29-56. https://doi.org/10.1007/978-3-319-01715-0_3 van Achterbergh E., Ryan C.G., Jackson S.E., Griffin W. 2001. Data reduction software for LA-ICP-MS. In: Sylvester P. (ed.), Laser Ablation ICPMS in the Earth Science. Canada, Mineralogical Association of Canada, p. 239-243.

Vermeesch P. 2004. How many grains are needed for a provenance study? Earth and Planetary Science Letters, 224(3-4):441-451. https://doi. org/10.1016/j.epsl.2004.05.037

Villaça J.N. 1981. Alguns aspectos sedimentares da Formação Moeda. Boletim da Sociedade Brasileira de Geologia Núcleo MG, 2:93-117.

Zavala C. \& Arcuri M. 2016. Intrabasinal and extrabasinalturbidites: Origin and distinctive characteristics. Sedimentary Geology, 337:36-54.

Zavala C., Arcuri M., Gamero H., Contreras C., Di Meglio M. 2011. Agenetic facies tract for the analysis of sustained hyperpycnal flow deposits. In: Slatt R.M., Zavala C. (eds.), Sediment Transfer from Shelf to Deep Water: Revisiting the Delivery System. American Association of Petroleum Geologists, Studies in Geology, 61, p. 31-51. https://doi.org/10.1306/13271349St613438 